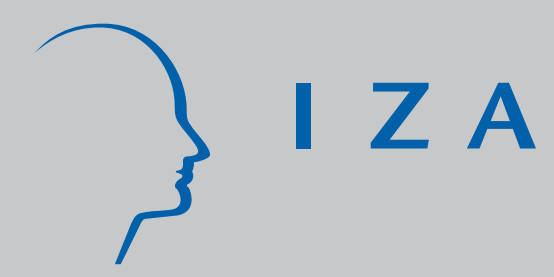

IZA DP No. 1168

Unemployment in the OECD:

Models and Mysteries

P. N. (Raj a) J unankar

J akob B. Madsen

J une 2004 


\title{
Unemployment in the OECD: Models and Mysteries
}

\author{
P. N. (Raja) Junankar \\ University of Western Sydney \\ and IZA Bonn \\ Jakob B. Madsen \\ University of Copenhagen
}
Discussion Paper No. 1168
June 2004

\author{
IZA \\ P.O. Box 7240 \\ 53072 Bonn \\ Germany
}

Phone: +49-228-3894-0

Fax: +49-228-3894-180

Email: iza@iza.org

\begin{abstract}
Any opinions expressed here are those of the author(s) and not those of the institute. Research disseminated by IZA may include views on policy, but the institute itself takes no institutional policy positions.
\end{abstract}

The Institute for the Study of Labor (IZA) in Bonn is a local and virtual international research center and a place of communication between science, politics and business. IZA is an independent nonprofit company supported by Deutsche Post World Net. The center is associated with the University of Bonn and offers a stimulating research environment through its research networks, research support, and visitors and doctoral programs. IZA engages in (i) original and internationally competitive research in all fields of labor economics, (ii) development of policy concepts, and (iii) dissemination of research results and concepts to the interested public.

IZA Discussion Papers often represent preliminary work and are circulated to encourage discussion. Citation of such a paper should account for its provisional character. A revised version may be available on the IZA website (www.iza.org) or directly from the author. 
IZA Discussion Paper No. 1168

June 2004

\section{ABSTRACT}

\section{Unemployment in the OECD: Models and Mysteries*}

This paper compares models used to explain OECD unemployment. The models suggest that the "natural rate of unemployment" has been driven up mainly by wage push factors. Panel data on twenty-two OECD countries are used to investigate the explanatory power of these models over the past two decades. Our estimates reveal that coefficients on key variables often turn out with signs which are at odds with the theories or are insignificant and that a second order autoregressive model performs nearly as well as all the other models. The conclusion offers some directions for future research.

JEL Classification: E24, J64, C52

Keywords: unemployment, natural rate, supply shocks, hysteresis

Corresponding author:

P.N. (Raja) Junankar

School of Economics and Finance

University of Western Sydney

Campbelltown Campus

Locked Bag 1797

Penrith South DC

NSW 1797

Australia

Email: raja.junankar@uws.edu.au

\footnotetext{
*We are grateful to Alec Chrystal, Steve Dowrick, John Driffill, Andrew Oswald, Adrian Pagan, and Felix Ritche, Tony Atkinson, Olivier Blanchard, Steve Nickell, Edmund Phelps, and John McCallum for helpful comments on an earlier draft.
} 


\section{UNEMPLOYMENT IN THE OECD: MODELS AND MYSTERIES}

\section{Introduction}

A key issue in macroeconomics is why has the unemployment rate in OECD countries increased over the past two decades and why it persists at relatively high levels. The four major models of Layard and Nickell (1986), Bruno and Sachs (1985), McCallum (1986), and Phelps (1992, 1994) suggest that the rate of unemployment has been mainly driven up by markups and especially various wage push factors. The authors' find empirical evidence in favour of their models using OECD data. However, the authors' have failed to deal adequately with the time-series properties of the data, except McCallum (1986), they have not exposed the models to adequate testing, and compared their results to other models. Further, they have used variables, which are not measured satisfactorily. This, in particular, applies to the key variables such as price competitiveness and inflation expectations.

We investigate whether the models are robust to different data and to different (and superior) panel data estimators. We estimate these models on a consistent data base of 22 OECD countries over the period 1960 to 1993 using best practice econometric estimation methods. Kmenta's (1986) GLS method and Hsiao's (1975) and Swamy's (1970) random coefficient estimators are used to yield short-run estimates. The between individual estimator is used in the long-run estimates as suggested by Baltagi and Griffin (1984).1 The advantage of the Kmenta estimator is that it is efficient, as compared to the OLS estimator, because it weights the covariance matrix used in the GLS estimator with the residual correlation across countries. Hsiao's random coefficient estimator allows for changing coefficients over time and across countries, whereas Swamy's estimator lets the coefficients vary across countries.

The random coefficient estimates are of particular relevance to the models of unemployment for four reasons. First, several of the variables used to explain unemployment are proxy variables. Proxy variables reflect only partially the signal of the variable they seek to account for and consequently lead to instability of the coefficients on the proxy variables (Dziechciarz (1990)). Second, the models use aggregate data to explain unemployment. Aggregation over individuals is another potential source of

1. The estimators are programmed in Gauss version 3.01. 
parameter instability (Zellner (1962)). Third, the models are only log-linear approximations of nonlinear models. As long as the variables move within a limited range the $\log$-linear approximation yields stable coefficient estimates. However, for large changes in the variables, the parameter estimates become unstable (Rausser et al. (1982)). Fourth, the Lucas critique suggests that the coefficients are likely to change over time since the models contain several expectational variables. Some would probably add to the list that the coefficients are likely to differ across countries and imposition of coefficient constancy across countries would therefore bias the estimates. However, as shown below, the coefficients are, for some perhaps surprisingly, similar across nations. Section 4 contains a more in depth discussion of our econometric method.

The approach of this paper follows Leamer (1995) in the sense that we seek to advocate which aspects of the models can be used to explain unemployment. This approach is fruitful since it is increasingly acknowledged that OECD unemployment is probably caused by multiple factors (see for instance Bean (1994)). Hence, simple models of unemployment are deemed to fail formal testing although they may have some useful attributes, which are important to build upon in future research. Moreover, we measure variables, which are not easily measured, using various proxies before dismissing the models outright.

Some recent papers have looked at the role of institutions in explaining OECD unemployment, see Nickell and Layard (1999) for a review of this literature, Nickell (1997), Blanchard and Wolfers (2000), Nickell et al. (2001), and Ball (1999). As most of the measures of "institutions" remain relatively constant over time, we do not get into that controversy as our estimation is based on differenced data which would eliminate such variables.

Before we give a more precise presentation of the models in section 5, we present a graphical comparison of the models in section 3. The presentation in section 3 indicates that the main models of unemployment are much more closely related to each other than the literature suggests. The empirical estimates of the models in section 5 suggest that most of the models are structurally unstable, and have coefficients on key variables, which are either statistically insignificant and have signs which are at odds with the predictions of the theories. However, our tests also suggest that the models offer some insights into our understanding of the OECD unemployment problem, in particular the contribution of job 
mismatch to the rise in unemployment. In section 6 we compare our results with the authors' own and we seek to explain why some of our conclusions are dissimilar to the authors' own.

\section{Unemployment Profiles Across OECD Countries}

Figure 1: Percentage Rate of Change of OECD Unemployment Rates

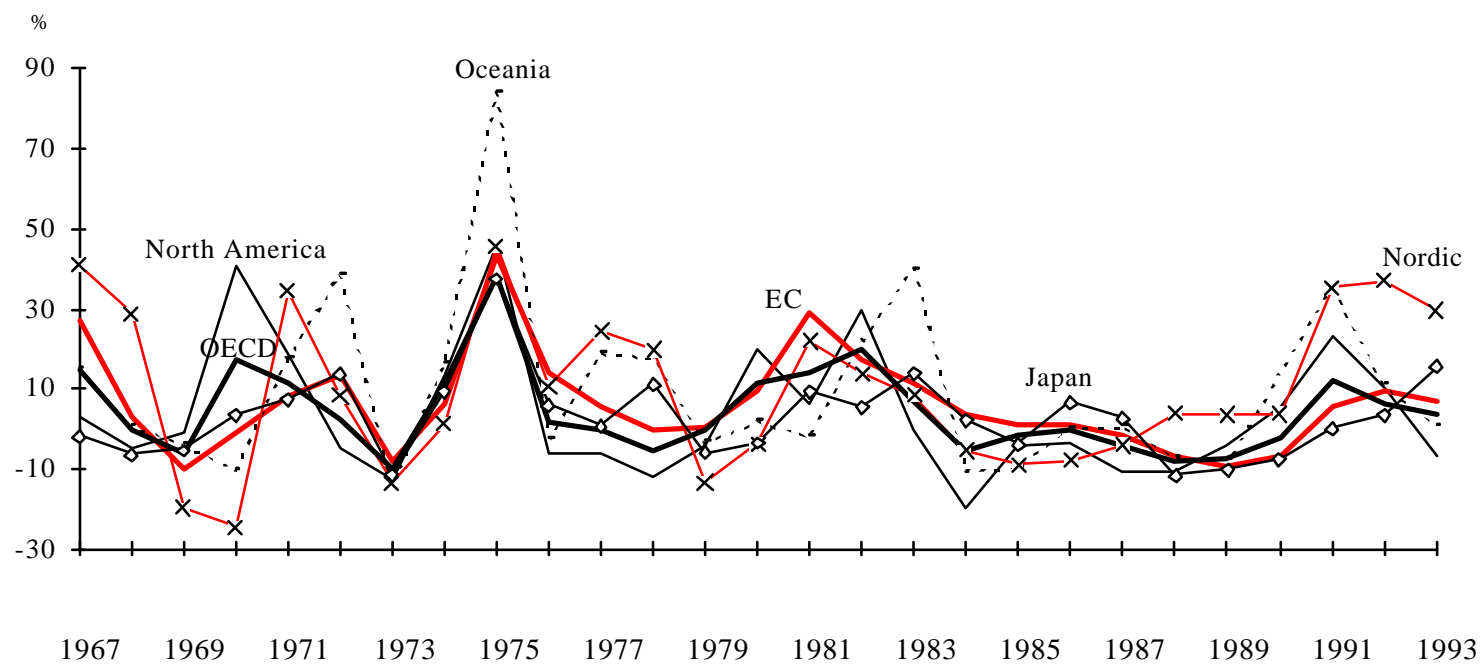

Figure 1 graphs the percentage rate of change of unemployment rates, which ignoring a few outliers, shows the similarity of the pattern of unemployment across such a diverse set of countries. Even Japan does not seem very different from the other countries. This suggests that to explain the unemployment rates of OECD countries we should have models which have some variables which are common to all of them, that is, some underlying variables which drive the economic systems of all the OECD countries. The graph furthermore suggests that unemployment is adequately measured in log firstdifferences when we pool across countries as log first-differences are approximately equal to percentage changes for small changes in the variables. We now turn to some of the models that have been used to explain unemployment in OECD countries.

\section{A Graphical Comparison of the Models}

The four models assume that unemployment is composed of cyclical and equilibrium unemployment (NAIRU), that unemployment is basically involuntary, and that the NAIRU is determined by relative 
prices (real wages, markups and real interest rates). The goods market is assumed to be perfectly competitive in the McCallum (1986), and Bruno and Sachs (1985, henceforth B\&S) models and imperfectly competitive in the Phelps $(1992,1994)$, and Layard and Nickell (1986, henceforth L\&N) models. Diagram 1 based on Layard, Nickell and Jackman (1991) can be used to summarise the structure of the models. WS represents the wage setting schedule and $\mathrm{Nd}$ represents the price setting or labour demand schedule.

\section{Diagram 1}

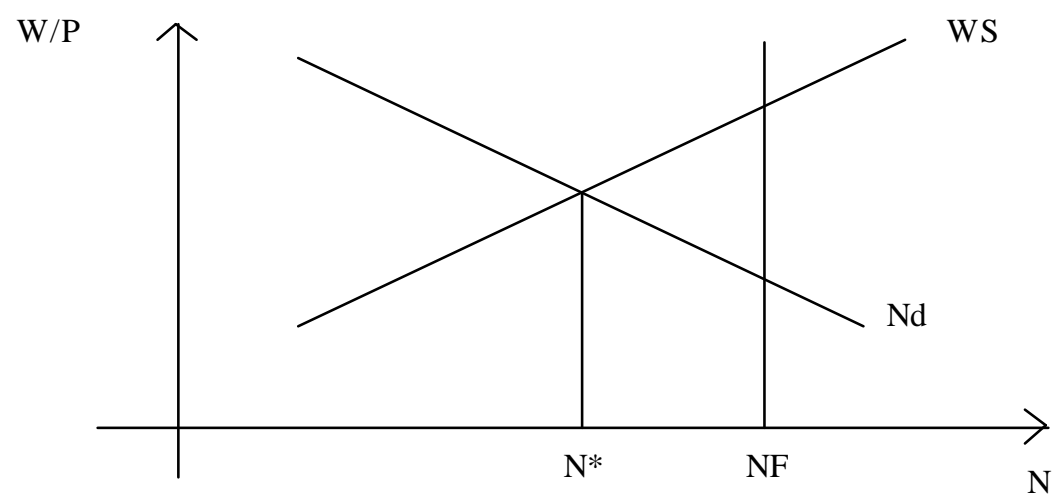

Equilibrium employment, $\mathrm{N}^{*}$, is determined by the intersection of the labour demand and the wage setting schedules. The real wage on the vertical axis is measured as total labour costs per hour worked divided by the value-added price-deflator, W/P, which is the relevant decision variable for the firm. Wage setting depends on the discrepancy between anticipated and actual prices, and other factors, which differ between the models. Labour demand depends on W/P, the discrepancy between anticipated and actual prices, and price markup over marginal cost. The labour force, NF, is depicted as independent of the real wage for expositional simplicity. Assuming labour market equilibrium, where price and wage expectations are fulfilled, (NF - $\mathrm{N}^{*}$ )100/NF defines the NAIRU. Actual unemployment in this framework can only deviate from the NAIRU if price and wage expectations are not fulfilled due to sticky wages, sticky prices, worker mis-information and/or producer mis-perception. The models then seek to explain unemployment as composed of the NAIRU and cyclical unemployment. 
L\&N model. In the L\&N framework the NAIRU has drifted upward over the past two decades due to excessive wages, which have been driven up by higher taxes, unemployment benefits, labour market mismatch and other wage push factors, which affect the wage setting schedule and the labour force participation rate. Unemployment may in the model be driven off its equilibrium (the NAIRU) by demand shift factors via two different channels: price expectational errors and changing markup over marginal cost. The expectational errors mechanism is the traditional AS-AD mechanism, at which exogenous demand shocks affect supply via expectational errors or contractual arrangements. The markup mechanism assumes that the demand elasticity varies procyclically, which in turn implies, that markups move countercyclically via the first order condition of profit maximization: $P=(1-\eta)^{-1} \mathrm{MC}$, where $\eta$ is price elasticity of demand.

B\&S model. In the B\&S framework, the NAIRU is measured as a transformation of the real wage gap, where B\&S define the real wage gap as the proportion of real wages in excess of the marginal productivity of labour at full employment. The real wage gap, in Diagram 1, is equal to the vertical distance between the intersection of the labour demand and the wage setting schedules and the intersection of the labour demand and the NF schedules. B\&S assume that the real wage gap is zero in the period 1965 to 1969 , and that wage push factors have been responsible for the leftward shift in the wage setting schedule, in particularly in the 1970s, and that labour demand shifted left due to the oil price shocks. The cyclical unemployment component in the B\&S model is assumed to be driven by cyclical demand shift variables such as world income and real monetary stock. Whether cyclical unemployment is a result of lack of demand (quantity constraints) or sticky wages is not explicitly stated in their exposition. Note, that though changes in the NAIRU in both the B\&S and the L\&N models are caused by wage push factors, $L \& N$ reject the real wage gap as a useful diagno stic tool to measure excessive wages. They argue, in particular in their 1986 paper, that both P/W and W/P are endogenous and hence that the real wage gap will not measure a structural tendency.

The McCallum model. This model is a reduced form AS-AD model in its purest form. The potential income, and hence the NAIRU, is determined in the labour market as the intersection of labour demand and wage setting. McCallum measures the equilibrium wage (the NAIRU) by means of real wages and 
a technology parameter, and deviations from the equilibrium by the traditional demand shift variables, which are usually incorporated in the IS-LM framework.

Phelps' model. The three models discussed above are very similar in spirit and their biggest difference is the way, in which they measure the disequilibrium wage and cyclical unemployment. However, the Phelps model differs substantially in spirit from the other models. An increasing NAIRU as a result of wage push factors is not central to Phelps' analysis (the only wage push factor he considers is the proportion of youths of the population of working age). The NAIRU is driven by three factors: (i) price markups over marginal costs; (ii) real interest rates; and (iii) factors that affect the ratio of wage to nonwage income.

Phelps uses the first order condition for profit maximisation: $P=\sigma(1-\eta)^{-1} M C$, where $\sigma$ denotes factors that affect markups other than the elasticity of demand. Given diminishing marginal product of labour, then labour demand is implied to be a declining function of $\sigma$. Phelps hypothesises $\sigma$ to be a positive function of the real effective exchange rate. A currency depreciation leads domestic producers to increase their markup instead of lowering their selling prices proportionally to the depreciation and hence increases the markup. Since Phelps assumes symmetrical adjustment in labour demand to varying $\sigma$, it is only capable of accounting for cross-country differences in the NAIRU and not the world NAIRU. Note that the transmission of real exchange rates to unemployment is quite different from that of McCallum and L\&N. Price competitiveness affects $\sigma$ only on a cyclical basis in the L\&N model. Price competitiveness has only demand side effects in the McCallum model.

The real interest rate plays a pivotal roe in the Phelps model. A shock to the economy, which drives up the real interest rate, affects labour demand adversely, because the discounted value of firms' investment in customers, fixed capital, and capital invested in employees all fall. This adverse labour demand effect is partially counterbalanced or may be reinforced by a shift in the wage setting schedule: on the one hand, the higher real interest rate lowers the real wealth position of the firms and hence the rent income paid to worker-shareowner households, which in turn lowers the propensity to quit or shirk, as the ratio of wage to non-wage income has risen. This effect shifts the wage setting schedule outward. 
On the other hand, the gross income to workers from higher interest rates shifts the wage setting schedule inward.

The low frequency movements in the real interest rates and real price competitiveness imply that labour demand moves on a low frequency basis. The increase in the real interest rate that occurred in the OECD countries in the 1980s, according to Phelps, is an important factor behind the increase in the NAIRU. Finally, dis-equilibrium unemployment in the Phelps model is triggered by price expectational errors as in the traditional AS-AD model.

\section{Econometric Method}

The four models of unemployment are estimated using various panel data techniques on 22 OECD countries, which includes all OECD member countries except Mexico, Iceland, the former Yugoslavia and Turkey, over the period 1960 to 1993.2 Four different estimators are used to estimate the models so that our results are not simply a result of our preferred estimation technique and to acknowledge that each estimator has its strengths and weaknesses. Most of the data are measured in log first differences since they contain a unit root (the variables which do not contain a unit root are measured in levels). Pesaran and Smith (1995) demonstrate that dynamic panel data models with variables containing a unit root tend to be dynamically unstable. Furthermore, as shown by Hamilton (1994), valid inferences with data containing unit roots can be made only in few special cases, for instance, if the variables are cointegrated and the t-ratios, attached to the coefficients, are transformed using the appropriate asymptotic standard errors. Finally, the first-difference estimator eliminates individual fixed effects (eg culture, institutions, legislation, etc). Since the unmeasureable individual effects are likely to be correlated with the explanatory variables estimates in levels would lead to inconsistent and biased parameter estimates. 3

2. Pooling of the data is in accordance with the authors' own estimates. Bruno and Sachs (1985) and LN (1985a, 1985b, 1986) estimate their model for single countries. However, Bruno (1986) tests the B\&S model with pooled cross-section and time-series data and Layard et al. (1986) estimate some of the models using a between country estimator.

3. In private correspondence, Steve Nickell and Edmund Phelps objected to our estimates on the grounds that the models should be estimated in levels. We re-ran all the equations in log-levels using the fixed effect 
The t-bar test suggested by Im, Pesaran and Shin (1995) is used to test for unit roots. The test, which uses panel data, is substantially more powerful than its time-series counterpart and is the most powerful within its class. The t-bar tests are reported in the square brackets in the data appendix.

The following four estimators are applied. The first three estimators are the generalised instrumental variable method of Kmenta (1986), the Hsiao (1975) random coefficient estimator, and the Swamy (1970) random coefficient model. These estimators use the data points both in the time and in the cross-section dimension. Whereas the random coefficient models are estimated over the whole data period the Kmenta model is estimated with data until 1988, and the period 1989-93 is used for forecasting and predictive failure tests. Although these estimators have several advantages to more traditional estimators they tend to miss out the long-run information contained in the data (Baltagi and Griffin (1984), Pesaran and Smith (1995)). Hence, we supplement the short-run estimates with between country estimates, which yield information about the long-run relationship (Baltagi and Griffin (1984), Pesaran and Smith (1995)). The between country estimates use the annual average growth over the entire sample period of each variable and for each country as one observation. White's heteroscedasticity consistent covariance matrix is used to calculate consistent standard errors following the recommendation of Pesaran and Smith (1995). The disadvantage of the between estimator is that it is generally inefficient, because it does not exploit the information contained in the time dimension (Pesaran and Smith (1995)).

The generalised instrument variable estimator of Kmenta weights the covariance matrix with the contemporaneous correlation between the residuals across countries and the cross-country heteroscedasticity. More specifically the following variance-covariance structure is assumed (Kmenta (1986)):

$\mathrm{E}\left(\varepsilon_{\mathrm{it}}^{2}\right)=\sigma_{\mathrm{i}}^{2}, \quad \mathrm{i}=1,2, \ldots \mathrm{N}$,

OLS estimator and the results severely violated the classical assumptions: there was severe heteroscedasticity, functional form problems, structural instability and serial correlation (the positive serial 
$\mathrm{E}\left(\varepsilon_{\mathrm{it}} \varepsilon_{\mathrm{j} t}\right)=\sigma_{\mathrm{ij}}, \quad \mathrm{i} \neq \mathrm{j}$,

where $\mathrm{N}$ is the number of cross-sectional units (countries), $\sigma_{\mathrm{i}}^{2}$ is its variance, $\sigma_{\mathrm{ij}}$ is the covariance of the disturbance terms across countries, and $\varepsilon$ is the disturbance term. The variance $\sigma_{i}^{2}$ is assumed to be constant over time but to vary across countries and the error terms are assumed to be mutually correlated across countries, $\sigma_{\mathrm{ij}}$, as random shocks are likely to impact on all countries at the same time. $\sigma_{\mathrm{i}}^{2}$ and $\sigma_{\mathrm{ij}}$ are estimated using the feasible generalised least squares method described in Kmenta (1986). This estimator is simple and efficient, but imposes coefficient constancy across countries. Ftests for coefficient constancy are performed for all models. Fixed effect dummies were initially included in the estimates using the Kmenta method, but deleted because they were jointly insignificant at the 1 percent level.

Hsiao's (1975) random coefficient estimator treats the coefficients as random draws across countries and over time and as such does not impose coefficient equality across countries and over time. Consequently, this estimator is even less restrictive than single country estimates provided that the time effect is stationary (first differences of the data certify that). Hsiao assumes that the coefficients on the explanatory variables are composed of three components: $\beta_{\mathrm{k}}+\delta_{\mathrm{ik}}+\gamma_{\mathrm{kt}}$, where $\beta_{\mathrm{k}}$ is invariant to time and individual (country), $\delta_{\mathrm{ik}}$ varies across individuals but is constant over time, and $\gamma_{\mathrm{kt}}$ varies over time but is constant across individuals. Further, he assumes that $\mathrm{E}\left\{\delta_{\mathrm{ik}}\right\}=0$ and $\mathrm{E}\left\{\gamma_{\mathrm{kt}}\right\}=0$. Hence, this estimator imposes a minimum number of restrictions on the coefficient estimates. As shown below this is particularly important in the time dimension. The disadvantage of the Hsiao estimator is that it is inefficient as compared to the Kmenta estimator, computationally burdensome, and the coefficient variances are often negative, which makes it difficult to draw inferences from the model.

The Swamy (1970) random coefficient model assumes that the coefficient vector on the explanatory variables is composed of a common coefficient vector $\left(\beta_{\mathrm{k}}\right)$ and a coefficient vector that varies across countries $\left(\delta_{\mathrm{ik}}\right)$ and that $\mathrm{E}\left\{\boldsymbol{\delta}_{\mathrm{ik}}\right\}=0$. The estimator weights the coefficient vector of each country inversely with its covariance matrix. Hence, this estimator is more efficient than single country estimates 
and does not impose any restrictions on the parameter estimates. This model is estimated with the same lag structure imposed as in the Hsiao estimates.

We do not undertake single country estimates for three reasons. First, the random coefficient estimates already provide a weighted average of (unrestricted) single country estimates. Second, as shown below, the hypothesis of cross-country coefficient homogeneity is difficult to reject, indicating common technology and behavior across countries. Third, single country estimates of the models in first differences end to yield statistically insignificant coefficient estimates and one will consequently not be able to discriminate against the null hypothesis and between the models. Furthermore, the time period is too short to allow for any meaningful dynamics in the estimation of these models.

The between individual estimator is used to yield long-run estimates as an alternative to the cointegration technique. Although cointegration techniques are useful in some circumstances we do not believe that it is the right bol to use in the present context for the following reasons. First, the number of variables exceed 10 in all models, except the B\&S model. "When the number of variables exceeds 10, the cointegration test tends to have rather poor small sample properties" (Pesaran (1996, p13). Second, proxies are used for many of the variables. However, the long-run time profiles of the proxy variables and the true variables are unlikely to be similar. This discrepancy will consequently interfere with the cointegration relationships between the variables. Examples of proxy variables that may not follow the path of the variables they are supposed to measure are income tax rates, the real wage gap and jobmismatch. The marginal tax rates are proxied by average tax rates. The long-run time profiles of marginal tax rates and the average tax rates are likely to differ. The long-run time profile of the real wage gap is sensitive to the technology assumption (Madsen (1994a)). Finally, there is no correct measure of job-mismatch and hence its long-run path is not well defined. A third problem with the cointegration technique is that the models are not properly identified by the authors. In our estimates we deal with this problem by using instruments. However, if one uses cointegration techniques the identification issue is more complex and if not dealt with properly the parameter estimates will be severely biased (see Pagan (1994) and Pesaran (1996) for strong views on this matter). Fourth, it is

the variables is unlikely to exist). 
increasingly acknowledged that multiple factors have caused the increase in OECD unemployment (Bean (1994)). Hence, each model is not likely to be an exhaustive model of unemployment and the models therefore cannot be truly cointegrated unless they contain all the factors which have caused the increase in unemployment. Fifth, whereas the rate of unemployment cannot increase without limit some of the explanatory variables can (for instance, real government debt, capital stock, and real government spending). Hence, a long-run relationship between the unemployment rate and these variables cannot logically exist (technically, the unbounded variables may form a cointegration vector between themselves; however, such a result is hard to reconcile with economic theory in the present context).

In the Kmenta estimates the regressors and the regressand are lagged one and two years and the model is estimated over the period 1964-1988. Predictive failure tests are performed over the period 19891993. The general-to-specific model reduction procedure is applied at the 1-percent level in the Kmenta estimates and the 10-percent level in the between estimates, reflecting the fact that the likelihood of rejecting the null hypothesis is a positive function of the sample size (Leamer (1978)). Furthermore, the variables with coefficients (ie the sum of the contemporaneous and lagged variables), which contradict the theory, are deleted; otherwise these coefficients will contribute to the explanatory power of a model and the model may hence gain over its rivals on false grounds.

The random coefficient models and the between estimator are estimated over the whole data period, otherwise we would run into degrees of freedom problems. The B\&S model is estimated with all variables lagged one period and the dependent variable lagged two periods as in the Kmenta estimates. However, the explanatory variables are not lagged and the dependent variable is lagged only one period in the other models for two reasons. First, NT $>(T+N-1) K$ in the Hsiao model, where $\mathrm{N}$ is the number of cross-section units (22), $\mathrm{T}$ is the number of time units (30) and $\mathrm{K}$ the number of explanatory variables. Consequently, $\mathrm{K}$ cannot exceed 11 in our sample, which makes it impossible to estimate the models with lags of all the variabes. Second, since the coefficients vary across countries and also over time in the Hsiao estimates the random coefficient estimators will yield imprecise coefficient estimates, if the number of regressors is high. Finally, the insignificant and wrongly signed variables are not deleted in the random coefficient estimates, partly because the coefficient variances may be negative, and partly because the random coefficient estimates are used for unrestricted comparisons. 


\section{The Models and Empirical Estimates}

The L\&N model. L\&N have estimated several different models to account for changes in unemployment over time and across countries. It is common for their models that equilibrium unemployment is a result of wage cost push factors. We estimate the seminal model of L\&N (Layard and Nickell (1985a); (1985b);(1986)), in a slightly modified version to allow for reduced form estimation, since their model consists of a system used to simulate causes of unemployment. The model we estimate is much in the spirit of the models of Grubb, Jackman and Layard (1983) and Andrews and Nickell (1982) (see also the discussion in Nickell ((1990) p. 433)).4 In most of L\&N's work they do not estimate an equation for unemployment but derive it as a reduced form from estimates of a system of equations of a wage equation, a price equation, labour demand (employment), and a trade balance equation. In more recent work, see Nickell (1997), Nickell et al (2001) have estimated equations for unemployment with essentially similar variables, but with some additional institutional variables. Since our estimation is based on first differences of logs, and most institutional variable are constant over this period, it does not significantly affect our results.

The reduced form L\&N unemployment equation is established by substituting their real wage equation into their labour demand function (which is similar to equation (36) in L\&N (1986)):

$\mathrm{u}=\mathrm{u}\left(\Delta \mathrm{p}^{\mathrm{u}}, \mathbf{p}^{\mathrm{w}}-\mathbf{p}^{\mathbf{o}}, \mathrm{g}^{\mathrm{c}}, \mathrm{y}^{\mathrm{cw}}, \mathrm{k}-\mathrm{n}, \mathrm{a}, \mathbf{M M}, \mathrm{v}\left(\mathbf{p}^{\mathrm{m}}-\mathbf{p}^{\mathbf{o}}\right), \rho, \mathbf{U P}, \mathbf{T}^{\mathrm{d}}, \mathbf{T}^{\mathrm{i}}, \mathbf{T}^{\mathbf{p}}\right)$

where lower-case roman letters are logs of the variable and the superscripts $\mathrm{c}$ and $\mathrm{w}$ signify cyclical and world. It is hypothesised that variables in bold type are positively related to unemployment, while the rest are negatively related to unemployment. (Note we shall follow this convention in subsequent equations.) Here, $\mathrm{u}$ is the unemployment rate, $\Delta \mathrm{p}^{\mathrm{u}}$ is unanticipated inflation, $\mathrm{p}^{\mathrm{V}}$ is the competitors'

\footnotetext{
4 Additional variables that account for changes in the equilibrium unemployment rate are considered in their most recent model (Layard et al. (1991)). These variables, however, are mostly not available over time and are likely to show little time variation. Moreover, many of the variables are created using subjective methods. It is for instance remarkable the extent to which their data on unemployment benefit (replacement
} 
prices on the import and export markets, $\mathrm{p}^{\mathrm{O}}$ is manufacturing output prices, $\mathrm{g}$ is the deviation of government real spending from its trend, $\mathrm{y}^{\mathrm{cW}}$ is the deviation of the world real income from its trend, $\mathrm{k}$ is net capital stock, $\mathrm{n}$ is the labour force, "a" is labour augmenting technological progress, MM is job mismatch, $v$ is the ratio of nominal imports to nominal GDP, $\mathrm{p}^{\mathrm{m}}$ is import prices, UP is union wage mark-up over non-union employees, $\rho$ is the replacement ratio, $\mathrm{T}^{\mathrm{d}}$ is direct tax rate, $\mathrm{T}^{\mathrm{i}}$ is the indirect tax rate, and $\mathrm{TP}^{\mathrm{p}}$ is employment tax rate and other indirect labour costs borne by the firm. The measurement of variables is defined in the data appendix.

The coefficients on $(\mathrm{k}-\mathrm{n})$ and "a" in the equation above are restricted by $\mathrm{L} \& \mathrm{~N}$ to be zero via crossequation restrictions in their estimates, because these variables are unbounded whereas the unemployment rate is not. Hence, we restrict the coefficients on $(\mathrm{k}-\mathrm{n})$ and "a" to be zero in our estimates. Data on UP are not available for most countries and are hence omitted from the regressions.

The first four independent variables in equation (1) account for cyclical unemployment: $\mathrm{p}^{\mathrm{u}}$ measures the effects of unanticipated price shocks as discussed above and the variables $\left(\mathrm{p}^{\mathrm{W}}-\mathrm{p}^{\mathrm{O}}\right), \mathrm{g}^{\mathrm{c}}$, and $\mathrm{y}^{\mathrm{cW}}$ are proxies of cyclical markups via their impact on the elasticity of demand. The last seven independent variables in equation (1) seek to explain the NAIRU.

Short-run estimates. Data on the replacement ratio are not available for some countries and over the whole period. Hence, we estimated the model in a separate regression using the data points for which the replacement ratio is available and with the mismatch variable omitted as we use several different measures of mismatch in the estimates below (this gave us 272 data points; see data appendix for details). Using the Kmenta estimator the coefficient on the replacement ratio was insignificant at any conventional significance levels ( $t$ - ratio was 0.64 for the unlagged coefficient and 0.06 for the lagged coefficient) and hence not considered as a potential contributor to the increase in the OECD unemployment. Chan-Lee et al. (1987) arrive at the same result for the OECD countries.

ratio) differ from the data collected by the OECD (see Chan-Lee et al. (1986)). We will consider some of their variables in the between individual estimates below. 
Four different variables were used for mismatch as this variable is not directly observable. The Kmenta estimator was applied in the preliminary estimates, where we select the appropriate mismatch variable for the final regression. The estimation results for the whole estimation equation are not shown as they are very similar to the final estimates. We used the ratio of long-term unemployed to total unemployment as the first measure of mismatch. Since data on long-term unemployment are not available before 1983 for most countries the sample period was relatively short and we consequently included the data up to 1993 in the estimates. This gave us 237 data points. The coefficients on the log of the ratio of long-term unemployment to total unemployment was $0.08(2.89)$, where the number in parenthesis is the tratio, and the coefficient on the lagged variable was insignificant. Hence, there is some evidence that long-term unemployment creates structural une mployment, which tends to lower the impact of aggregate unemployment on (the growth of) real wages. However, with an elasticity of 0.08 long-term unemployment only has a marginal impact on unemployment. As the second measure of mismatch, we used the population in the age of 20 to 24 relative to the population of working age. The coefficients on this variable were insignificant indicating that the age structure is probably not an important source of structural unemployment. Thirdly, we used the proxy suggested by Bean, Layard and Nickell (1986) as a measure of unemployment benefits levels, search intensity and other changes in the labour market structure. The proxy is given by:

$\Delta \mathrm{U}_{\mathrm{t}}=\gamma_{0}+\gamma_{1} \Delta \mathrm{V}_{\mathrm{t}}+\gamma_{2} \Delta \mathrm{U}_{\mathrm{t}-1}+\gamma_{3} \mathrm{U}_{\mathrm{t}-1}+\gamma_{4} \mathrm{~V}_{\mathrm{t}-1}+\gamma_{5} \mathrm{t}+\gamma_{6} \mathrm{t}^{2}$

where $\mathrm{V}$ is the vacancy rate. We estimated this equation for each individual country and used the expression $\left(\gamma_{5} t+\gamma_{6} t^{2}\right) / \gamma_{3}$ to represent the shift in the unemployment-vacancy ratio over time. We did not measure $\left(\gamma_{5} \mathrm{t}+\gamma_{6} \mathrm{t}^{2}\right) / \gamma_{3}$ in first differences since it would otherwise produce a near singular X-matrix. This is of course problematic since $\left(\gamma_{5} t+\gamma_{6} t^{2}\right) / \gamma_{3}$ is neither trend stationary nor first-difference stationary. However, there is not much one can do about this problem. The coefficient on $\left(\gamma_{5} t+\right.$ $\left.\gamma_{6} t^{2}\right) / \gamma_{3}$ turned out to be insignificant in the estimates. As the fourth proxy for mismatch we used the log of ratio of manufacturing to total employment to allow for the influence of the manufacturing decline since the first oil price shock in most OECD countries, on unemployment. Junankar (1981), Junankar and Price (1984), and Glyn and Rowthorn (1988) have observed that male full-time workers made redundant in the manufacturing sector, since the first oil price shock, have not found it easy to find 
employment in the growing service sector which has hired mainly female part-time workers. Layard et al. (1991) use a measure for mismatch, which is closely related to our measure; namely the absolute change in manufacturing employment. The problem with their measure, however, is that employment may be declining equally in all sectors of the economy and yet no structural unemployment has developed although manufacturing employment has declined. The share of manufacturing employment in total employment was significant and with the right sign, and is consequently maintained as the preferred measure of mismatch in the regressions presented in Table 1.

Table 1. Parameter estimates of the L\&N model (equation 1).

Table 1 presents the results of estimating the L\&N model. First, the estimates using the Kmenta estimator (first column). The coefficients on payroll taxes and $v\left(\mathrm{p}^{\mathrm{m}} \mathrm{p}^{\mathrm{O}}\right)$ had signs opposite to those predicted by the model and therefore deleted. The sum of the coefficients on $\left(\mathrm{p}^{\mathrm{W}}-\mathrm{p}^{\mathrm{O}}\right)$ was zero and therefore also deleted. Finally, the price expectation error coefficients were positively signed and very significant, contrary to the predictions made by the theory. This is a quite serious matter as it implies either one or both of the following: either that aggregate supply is independent of price surprises, in which case the $\mathrm{AD}$-AS framework and the natural rate hypothesis demolishes and/or that we do not measure price expectational errors correctly. We obtained the same result if we measured expected inflation as actual inflation in the previous year. Hence, even if inflation expectations are formed adaptively or extrapolatively inflation expectational errors cannot account for cyclical unemployment.

The classical F-test rejects the hypothesis of coefficient constancy across countries, at the 1-percent level. However, there are three problems with the classical Ftest. First, it over-rejects the null hypothesis (Baltagi (1995)). Second, it does not account for the efficiency gain from pooling (McElroy (1977)). Third, it does not take into account that the likelihood of rejecting the null hypothesis is an increasing function of the number of observations. Leamer (1978, p114), suggests an alternative formula, which accounts for the number of observations. Using this formula the null hypothesis of coefficient constancy across countries cannot be rejected, at any conventional significance level. 
The diagnostic tests do not give evidence against the specification of the model, except the Chow test, which indicates that the model is structurally unstable (even if the number of observations are taken into account). Consequently, the assumption of coefficient constancy over time is more restrictive than the assumption of coefficient constancy across countries in this model. The structural instability of the model suggests that the model is either misspecified or that the coefficients have changed over the sample period. The coefficients could have changed over the sample period because they tend to be biased towards zero in periods of overemployment, as in the late 1960s and in the beginning of the 1970. In such a situation unemployment cannot be reduced much further and the genuine impact of the regressors on unemployment will not be reflected in the estimates. We therefore re-estimated the model with data over the period 1973 to 1993 . However, the coefficients on the structural variables hardly changed, as compared with the estimates over the estimation period 1964-1989, so coefficient instability is unlikely to be the cause of the structural instability.

Turning to the coefficient estimates in Table 1 the cyclical variables explain most of the variance of the model, particularly cyclical world incomes, as revealed by the t-statistics. The only NAIRU variables which survive the model reduction are job mismatch and direct taxes. To evaluate the consequences on unemployment of the change in the direct tax rate and mismatch it is not informative to focus on the coefficient estimates when the (log of the) rate of unemployment is the dependent variable, because it has fluctuated substantially over the estimation period. The essence is that we are interested in the percentage point change, and not the percentage change in the rate of unemployment caused by the regressors. An xpercent increase in unemployment has quite different implications for the level of unemployment when the rate of unemployment is 1 percent as compared to 10 percent. Hence, we simulate the effects of the actual changes in direct taxes and mismatch over the period from 1973 to 1993 on unemployment using the Kmenta estimates. The simulation results reveal that the direct tax rates have pushed the unemployment rate up by 0.61 percentage points for the average OECD country. 6 The corresponding figure is 4.87 for mismatch. Hence, the increasing $N A I R U$, in the $L \& N$

\footnotetext{
5 However, that still leaves unsolved why world income deviated from trend.

6 Some may be puzzled by the finding that unemployment is affected by direct taxes and not payroll taxes, indirect taxes and imported inflation. However, the result is perfectly consistent with our estimates of a wage equation/ Phillips curve, where the direct tax rate turned out to be the tax variable with the highest elasticity. The results are available from the authors upon request.
} 
model, is largely explained by the relative decline in manufacturing employment. It is, however, to be explained why manufacturing employment has decreased since the first oil price shock, a discussion we will return to in the concluding section.

The results of estimating the random coefficient models are shown in the second column of Table 1 . The coefficients are less significant than estimates where the coefficients are restricted to be the same over time and across countries, because the variance of the coefficients over time and across countries increase the coefficient standard deviations. The coefficient estimates are quite similar to the Kmenta estimates. World income and mismatch again explain most of the variance of unemployment.

Long-run estimates. Separate regressions were run for the replacement ratio and the four considered measures of mismatch, with all variables measured over the time-span, in which data for all the variables are available. However, none of the coefficients had the right sign or were significant and the regression results are therefore not reported. Mismatch and direct taxes had the right signs but were only significant at the 16 and 19 percent levels. We found the same result if instead we averaged the variables over the period 1973-1993. Combining this result with the short-run estimates it can be concluded that the decline in relative employment in manufacturing has only had short-run consequences for unemployment and that it cannot explain cross-country differences in unemployment. This result can be interpreted in two ways. First, if one assumes that mismatch affects unemployment through the wage equation, as L\&N (1986) do, it does not have a long-run effect on unemployment if unemployment impacts on the rate of real wage growth as in the Phillips-curve (note that $\mathrm{L} \& \mathrm{~N}$ assume away this possibility as unemployment affects only the level of real wages in their 1986 paper). If mismatch pushes wages above the full employment equilibrium, unemployment will put downward pressure on real wage growth until unemployment is eliminated. A second possibility is that the decline in manufacturing employment relative to total employment initially resulted in an increase in unemployment. However, over time the redundant workers have been re-educated, moved to more prosperous regions, or dropped out of the labour force. We cannot exclude, though, that the relative manufacturing decline has been an important contributor to the rise in the OECD unemployment since the short-run estimates suggest that this effect is very strong. Furthermore, unemployment is significantly related to the change in relative manufacturing employment using the between estimator suggesting that a much more detailed 
study on this matter needs to be undertaken to reveal the contribution of the decline in manufacturing employment to the rise in unemployment.

As a final check on the L\&N model the average change in unemployment was regressed on the 6 variables for labour market distortions emphasised by Layard et al. (1991). The variables, which are from the data appendix and table 7 in chapter 9 of Layard et al. (1991), are: the replacement ratio, the duration of unemployment benefits, the percentage of workers covered by collective agreements, coordination between workers and employers, and government job search assistance. All variables turned out to be insignificant, at the 10 percent level. Ball (1996) arrives at the same result by regressing the change in the NAIRU from 1980-1990 on the same variables.

The B\&S model. According to Bruno and Sachs (1985), Bruno (1986) and Sachs (1983), the rise in the real wage gap has contributed to the rise in the unemployment in the OECD countries, in particular after the first oil price shock. As noted above, B\&S define the real wage gap as the proportion of real wages in excess of the full employment marginal productivity of labour: $\mathrm{w}^{\mathrm{x}}=\mathrm{w}-\mathrm{p}^{\mathrm{va}}-\log \left(\mathrm{MPN}^{\mathrm{f}}\right)$, where $\mathrm{w}$ is hourly labour costs, $\mathrm{p}^{\mathrm{va}}$ is the value-added price-deflator and $\mathrm{MPN}^{\mathrm{f}}$ is the marginal product of labour at full employment.

Bruno and Sachs have estimated different specifications of their model. We estimate the most general model estimated by B\&S, which appears in Bruno (1986). Bruno (1986) regresses unemployment on the real wage gap and cyclical shift variables:

$\mathrm{u}=\mathrm{u}\left(\mathbf{w}^{\mathrm{x}},\left(\mathrm{m} 1-\mathrm{p}^{\mathrm{cpi}}\right)^{\mathrm{c}}, \mathrm{y}^{\mathrm{cw}}, \mathbf{D 7 5}\right)$,

where $\mathrm{m} 1$ is the $\log$ of monetary stock, $\mathrm{M} 1, \mathrm{p}^{\mathrm{cpi}}$ is consumer prices, and D75 is a constant dummy taking the value 0 before 1975 and 1 after. D75 is omitted from the estimates as no rationale is given for its inclusion, and the variable is likely to explain segments of the rise in unemployment after 1974, which the other explanatory variables may not be able to explain. The full employment marginal product of labour is in line with Bruno (1986) computed under the assumptions of CES technology and Hicks neutral technological progress using the approximation formula: 
$\log \left(\mathrm{MPN}^{f}\right)=\log (\mathrm{Y} / \mathrm{N})^{\mathrm{f}}+((1-\sigma) / \sigma) \mathrm{S}_{\mathrm{k}} \log \left(\mathrm{K}_{\mathrm{N}} \mathrm{N}^{f}\right)$

where $(\mathrm{Y} / \mathrm{N})^{\mathrm{f}}$ is the full employment labour productivity, $\sigma$ is the elasticity of substitution between labour and capital, $\mathrm{S}_{\mathrm{k}}$ is the share of capital in national product, $\mathrm{K}$ is net capital stock and $\mathrm{N}$ is the full employment, which is set equal to the labour force. The second term on the right hand side of equation (3) approaches zero as $\sigma$ approaches one; that is the Cobb-Douglas case. If $0<\sigma<1$ and $\mathrm{S}_{\mathrm{K}}$ constant, an increase in the $\mathrm{K} / \mathrm{N}$ ratio enlarges the marginal productivity of labour, and hence the warranted real product wage. $\log (\mathrm{Y} / \mathrm{N})^{\mathrm{f}}$ is estimated as the predicted value from regressing $\log (\mathrm{Y} / \mathrm{N})$ on a time trend and a squared time trend, where $\mathrm{Y} / \mathrm{N}$ is measured as real GDP divided by total hours worked. This method avoids end-point extrapolation, which is connected to the trend-through-peak method applied by B\&S. $\sigma$ is set to 0.5 in line with Bruno (1986) and $S_{\mathrm{K}}$ is measured as the net operating surplus divided by nominal GDP for the whole economy. 7

Table 2. Parameter estimates of the B\&S model (equation 2).

Short-run estimates. The results of estimating the B\&S model using the Kmenta estimator are presented in the first column of Table 2. The diagnostic tests suggest that the model is well specified and is structurally stable. The F-test for pooling shows cross-country coefficient homogeneity. The coefficient estimates of all the independent variables have the expected signs and are significant. Most of the action comes from the cyclical shift variables, though the real wage gap is also quite significant. The real wage gap has its strongest effect on unemployment after one year, due to employment adjustment lags. To evaluate the contribution of the real wage gap on unemployment in the OECD we simulated the model over the period 1973 to 1993. The simulation results indicate that the average OECD country experienced a 0.41 percentage point increase in the unemployment rate due to the real wage gap over that period. Note that the profile of the real wage gap in the OECD countries has been

\footnotetext{
${ }^{7}$ For comparative purposes, the B\&S unemployment equation was estimated under the Cobb-Douglas technology assumption, ie $\sigma=1$. However, this resulted in a substantial reduction in the explained variance (about 10 per cent) compared with the estimates, where $\sigma=0.5$.
} 
somewhat bell shaped over the period from the mid 1960s to 1993 . Hence, the real wage gap may have been an important contributor to the initial rise in unemployment in the mid 1970s.

Turning to the random coefficient estimates in column 2 of Table 2 the coefficient estimates are strikingly similar to those of the Kmenta estimates. The only difference is that the coefficient on the real wage gap is higher in the random coefficient estimates, which suggests that the contribution of the real wage gap to unemployment, in the simulations above, are in the lower range. The similarity between the estimates suggest that there is a robust positive relationship between the real wage gap and unemployment.

Long-run estimates. The coefficient on the real wage gap in the between estimates in table 2 is significant and its magnitude is quite similar to the short-run estimates. This result reinforces that real wage gap is a statistically significant, though not economically significant, contributor to the rise in the OECD unemployment.

McCallum's model. This model is given by the equation:

$\mathrm{u}=\mathrm{u}\left[\Psi\left\{\mathrm{g}^{\mathrm{c}},\left(\mathrm{m} 1-\mathrm{p}^{\mathrm{cpi}}\right)^{\mathrm{c}}, \nu\left(\mathbf{p}^{\mathrm{m}}-\mathbf{p}^{\mathrm{va}}\right), \mathbf{p}^{\mathrm{w}}-\mathbf{p}^{\mathbf{o}}, \mathbf{u}^{\mathrm{w}}\right\}, \Psi v\left\{\mathrm{~g}^{\mathrm{c}},\left(\mathrm{m} 1-\mathrm{p}^{\mathrm{va}}\right)^{\mathrm{c}}, \mathrm{p}^{\mathrm{w}}-\mathrm{p}^{\mathrm{o}}, \mathbf{u}^{\mathrm{w}}\right\}, \varepsilon\left(\mathbf{w}-\mathbf{p}^{\mathrm{va}}\right)\right]$

where $\Psi$ is the ratio of Okun's Law coefficient to the world average, $v$ is the ratio of openness of the economy to the world average, $\varepsilon$ is the ratio of the real wage elasticity of labour demand to the world average, and $\mathrm{u}^{\mathrm{W}}$ is world unemployment. The variables $\mathrm{g}^{\mathrm{c}},\left(\mathrm{m} 1-\mathrm{p}^{\mathrm{cpi}}\right)^{\mathrm{c}}, \mathrm{p}^{\mathrm{w}}-\mathrm{p}^{\mathrm{o}}$ are the usual arguments in the reduced form aggregate demand curve and $\mathrm{p}^{\mathrm{m}}-\mathrm{p}^{\mathrm{va}}$ affect real income via its impact on the purchasing power of the economy, where $\mathrm{p}^{\mathrm{m}}$ is import prices. (w-p) represents the supply side of the economy. $\Psi$ and $\varepsilon$ are estimated from auxiliary single country regressions over whole sample period (see data appendix). As equation (5) stands, a continuously increasing real product wage implies an ever increasing unemployment rate as there are no counter-balancing forces in the model. However, McCallum is aware of this problem, and assumes constant growth in the marginal productivity of labour in the estimation period. Hence, when he estimates in first differences this effect is picked up by the constants. 
Note that $\left(\mathrm{p}^{\mathrm{w}}-\mathrm{p}^{\mathrm{o}}\right)$, in contrast to the $\mathrm{L} \& \mathrm{~N}$ framework, is assumed to be inversely related to unemployment, because it has a positive demand side effect and no supply side effect. This difference is not a result of internal inconsistency in the L\&N framework as it is implicitly assumed that any demand effects, including the demand effects from changing competitiveness, feed into unemployment via price expectational errors. Furthermore, $L \& N$ assume that $\left(\mathrm{p}^{\mathrm{w}}-\mathrm{p}^{\mathrm{o}}\right)$ affects mark-up positively and hence lowers the demand for labour. The McCallum model assumes perfect competition and hence a fixed price markup. Furthermore, McCallum may have felt that demand shocks may also affect employment via quantities, however, he is not explicit about this issue. 8

McCallum's use of the world unemployment rate as an explanatory variable is inappropriate. The comovements of unemployment across countries over time in log first differences (figure 1) suggests that this variable explains a substantial part of the single country unemployment without adding insight into the causes of the rise in unemployment. To put it in another way, we need to explain why the world unemployment rate varies: we need some variables that explain variations in the world unemployment rate otherwise we are not explaining variations in OECD country unemployment rates.

Table 3. Parameter estimates of the McCallum model (equation 5).

Short-run estimates. As this model contains a large number of regressors the random coefficient models are estimated with the $\psi v$-variables excluded. The results of estimating the McCallum model using the Kmenta estimator are presented in the first column of table 3. The diagnostic tests reveal heteroscedasticity and structural instability, which point toward misspecification of the model. The cyclical variables explain the bulk of the variance of unemployment, particularly the deviation of the real monetary stock from its trend. The coefficient of more than 0.6 on the world unemployment confirms the high co-movements in unemployment across the OECD countries as displayed in figure 1 . In the Swamy estimates the coefficient on world unemployment is close to one, which is not surprising given that its slope is allowed to vary across countries. Note, however, that world unemployment is

8 In private correspondence John McCallum did not disagree with our approach or our results. 
economically and statistically insignificant using the Hsiao estimator, indicating that time aggregation has caused a spurious relationship between domestic and world unemployment.

Weighted real wages, as the only structural variable in the McCallum model, is not statistically significant in any of the estimates. Coupled with the fact that the demand side variables are measured as deviations from their trend the model is therefore not capable of explaining the increase in trend unemployment. Consequently, we have not carried out any simulations of the model.

Long-run estimates. We did not perform between estimates of the model, because there is no natural way the model allows us to do that. The cyclical variables, per construction, cannot explain the long-run impacts. Real wages cannot be used either because the warranted real wage growth needs to be deducted from real wages to find the disequilibrium wage. However, the McCallum model does not offer any insight into this aspect. A natural extension would be to use the real wage gap, but that has already been done in the $\mathrm{B} \& \mathrm{~S}$ estimates.

The Phelps model. Phelps (1994) estimates a reduced form unemployment equation, which draws heavily on the general equilibrium models of Hoon and Phelps (1992) and Phelps (1992) and the model of Fitoussi and Phelps (1988):

$\mathrm{u}=\mathrm{u}\left(\Delta \mathrm{p}^{\mathrm{u}}, \mathbf{p o p}^{\mathrm{y}}, \mathbf{D}^{\mathrm{g}}, \mathrm{k}, \mathbf{g}, \mathbf{T}^{\mathrm{d}}, \mathbf{T}^{\mathrm{p}}, \mathbf{I R}^{\mathrm{w}}, \mathbf{o r}^{\mathrm{w}}, \mathbf{p}^{\mathrm{w}}-\mathbf{p}^{\mathbf{o}}\right)$

where $\operatorname{pop}^{\mathrm{y}}$ is the proportion of population of 20 to 24 years of age, $\mathrm{D}^{\mathrm{g}}$ is government net debt, $\mathrm{IR}^{\mathrm{w}}$ is the world real interest rate, and or $^{\mathrm{w}}$ is the real USD price of oil. All the independent variables in equation (6), except $\mathrm{p}^{\mathrm{u}}$, seek to explain the NAIRU. $\mathrm{p}^{\mathrm{u}}$ is supposed to account for cyclical unemployment caused by price and wage expectational errors on the part of producers and workers.

The NAIRU is affected by several factors in the Phelps model. Government spending adversely affects economic activity, because the adverse real interest rate effects on investment in customers, workers and fixed capital more than counterbalances the demand stimuli, which is in sharp contrast to Keynesian 
models.9 Government debt is also positively related to unemployment because it increases the real interest rate. Capital stock has a positive impact on employment as it increases in the marginal productivity of labour. The direct tax rate affects unemployment solely to the extent that it is capable of influencing the ratio of after-tax wage income and after-tax non-wage income. If wage income is taxed more heavily than non-wage income, due to tax evasion etc of non-wage income, as assumed in equation (6), it gives an incentive to work less, as the relative return to non-wage income has gone up. Since indirect taxes do not affect the ratio of wage and non-wage income, they will not affect unemployment. Pay-roll taxes reduce after-tax wage rate available to workers as a ratio to non-wage income, which in turn increases the equilibrium unemployment as the quit rate increases. The mechanism by which the world real oil price affects unemployment is different from the B\&S story. According to B\&S adverse oil price shocks are contractionary, as they increase real unit labour costs via two channels. First, oil price shocks adversely affect productivity, and hence the feasible real wage growth. However, since real wages are assumed to grow at a target rate, real wages are pulled off their full employment equilibrium. Second, oil price shocks push consumer prices, to which wages were indexed to, above the value-added prices, and wages are pushed even further off the full employment equilibrium. By contrast, a real oil price rise is in the Phelps model assumed to tilt the income distribution in favor of non-wage income (royalties), which in turn increases the propensity to quit. $\mathrm{p}^{\mathrm{w}}$ $\mathrm{p}^{\mathrm{o}}$ affect unemployment positively via the markup mechanism similar to the one of L\&N. Finally, it is worth noting that government expenditure and government debt count twice in equation (6) as they are assumed to transmit to unemployment via the real interest rate, which is already included in the equation. However, we maintain government expenditure and government debt in the estimates of equation (6) to make our estimates comparable with Phelps'.

Table 4. Parameter estimates of the Phelps model (equation 6).

Short-run estimates. In accordance with Phelps' estimates, the coefficients on $\Delta \mathrm{u}_{\mathrm{t}-1}$ and $\Delta \mathrm{u}_{\mathrm{t}-2}$ were first allowed to vary for the country groups North America, Scandinavia, the rest of Europe, and

9With misperception and wage/ price stickiness built into the Hoon and Phelps (1992) model, govemment spending will not necessarily have negative income effects. The net effect depends on the joint effects from $\mathrm{g}$ and $\mathrm{pu}$. 
Australia and New Zealand. Since the null hypothesis of coefficient equality of the coefficients on the lagged dependent variables could not be rejected, at the 1-percent level, the coefficients were restricted to be the same for all countries. The results of estimating the Phelps model, using the Kmenta estimator, are presented in the first column of Table 4. The model is structural unstable. The other diagnostic tests do not give evidence against the model specification. Half of the explanatory variables were deleted since the coefficients had signs which did mt accord with the theory. In particular, the world real interest rate, which is a key Phelps variable, was incorrectly signed. The influence of the world real interest rate on unemployment is taken up in section 7 as it depends crucially on how inflation expectations are measured. Most of the variation of unemployment is explained by direct taxes. The high magnitude of the constant term indicates that important explanatory variables are omitted for the model. The constant term shows that autonomous forces (omitted variables) in the sample period have annually increased unemployment by 9 percent. If unemployment is already a double digit number the contribution to unemployment from this term is substantial.

Simulations of the model show that direct taxes have contributed 0.97 percent points to unemployment in the average OECD country over the period from 1973 to 1993 . The corresponding number for Popy is a 0.01 percent point fall, and the capital stock has hardly affected unemployment. The impact of competitiveness on unemployment is not simulated as it nets out to almost zero for the average OECD country and only explains cross-country differences.

That direct taxes have contributed to the rise in the OECD unemployment in the estimates of the Phelps model begs the question of identification: do direct taxes affect unemployment via the tax evasion channel or via wage push, as in the L\&N model? Since the coefficient on direct taxes in the wage equation are consistent with the estimates of the unemployment equation one may suspect that transmission via tax evasions play a minor role for unemployment.

Turning to the random coefficient estimates note that the Phelps model cannot be estimated using the Hsiao estimator, because real oil prices and the world interest rates are identical for all countries and hence show no variation in the country frequency domain (which is required to estimate the timevariation of the coefficients). The Swamy estimates are consistent with the Kmenta estimates, though 
hardly any of the explanatory variables are significant. The sign of the coefficient on the world real interest rate is again inconsistent with Phelps' theory.

Long-run estimates. The world real interest rate and real oil prices were omitted from the between estimates as they by construction do not show cross-country variation. All significant coefficients had signs, which disagree with the predictions of the model. Combining this result with the results above, the Phelps model is not likely to add much to our understanding of the rise in the OECD unemployment.

\section{Comparison of the Empirical Performance of the Models}

The models are compared in terms of different criteria. We distinguish between two broad criteria: within sample and post sample model performance. The within sample criteria consist of model selection criteria. The model selection criteria considered are $\mathrm{R}^{2}$, Akaike's information criteria (AIC), and J-tests, which tests whether attributes of one model can increase the explanatory power of another model. The post sample model criteria consist of predictive failure tests, and the mean squared errors and the mean absolute errors in the forecast periods 1989 to 1993. Finally we compare the performance of the models with a second order auto-regressive model of $\Delta \mathrm{u}_{\mathrm{t}}$ :

$\Delta \mathrm{u}_{\mathrm{t}}=0.17 \Delta \mathrm{u}_{\mathrm{t}-1}-0.23 \Delta \mathrm{u}_{\mathrm{t}-2}+0.05$,

(5.85) (4.88) (4.81)

$\mathrm{R} 2=0.09 \mathrm{PF}=13.9 \mathrm{MSE}=0.19 \mathrm{MAE}=0.21 \mathrm{~F}(44,594)=1.37, \operatorname{Chow}(14,654)=31.27$,

where the symbols are explained in the notes to Table 1. It is interesting to note that the hypothesis of cross-country coefficient homogeneity is easily accepted in this estimate suggesting that unemployment follows the same autoregressive pattern across countries. This result is consistent with the impression one gets from looking at Figure 1, but not with the hypothesis that unemployment is more persistent in Europe than other OECD countries as often suggested in the literature. Another interesting feature of equation (7) is that unemployment increases by 5 percent annually due to autonomous forces (omitted variables), as indicated by the constant term. This number is substantially lower than the 
constant term in the Phelps estimates and equal to the constant term in the B\&S estimates. Clearly, some important variables have been omitted from these models.

Table 5: Model Comparison

\begin{tabular}{|ll|l|l|l|l|}
\hline Model & Wrong signs $^{\mathbf{1}}$ & $\mathbf{R}^{\mathbf{2}}$ & AIC & J-test $^{\mathbf{2}}$ & MSE \\
\hline L\&N & $44 \%$ & 0.87 & 0.68 & Mc:16.1 Ph: 0.0 B\&S: 7.7 & 0.15 \\
\hline B\&S & $0 \%$ & 0.86 & 0.64 & Mc:5.4 Ph: 0.3 L\&N: 0.6 & 0.20 \\
\hline McCallum & $0 \%$ & 0.86 & 0.58 & Ph: 6.2 B\&S: 0.2 L\&N: 0.0 & 0.21 \\
\hline Phelps & $40 \%$ & 0.94 & 0.64 & Mc:13.6 B\&S: 0.1 L\&N: 0.6 & 0.32 \\
\hline Autoregressive & Not applicable & 0.09 & 0.89 & & 0.19 \\
\hline
\end{tabular}

Source: tables 1-4, column 1, and equation (7).

1. At 1-percent significance level.

2. J-test of whether attributes of the models of Mc (McCallum), Ph (Phelps), L\&N, and B\&S increase the explanatory power of the models, $c^{2}(1)$-distributed under the null hypothesis of no contribution. Note that the predicted value of all the models are simultaneously included in the J-test regression.

Within sample comparison. Table 5 provides a summary comparison of the models. The first column provides a summary of the proportion of variables which do not satisfy the a priori sign restrictions. It appears that the $L \& N$ and the Phelps models do not perform well on this criterion. Though the McCallum model has more explanatory variables than the L\&N and the Phelps models, none of the coefficients were wrongly signed, at the 1-percent level. Since, nearly all of the regressors in the McCallum model are demand shift variables, this result indicates that demand side factors are consistently important determinants of cyclical unemployment, whereas supply side factors have less clear-cut effects on unemployment. The Akaike Information (AIC) and the $\mathrm{R}^{2}$ criteria suggest that the 4 models are superior to the simple autoregressive model. This is to be expected since an increased number of regressors nearly always increase the significance of a regression equation. A much more informative within sample criterion uses non-nested J-tests, which test whether one model has attributes that increase the explanatory power of the other models. Clearly, the McCallum model is the winner on this score: it contains attributes, which increase the explanatory power of all models, at the 1-percent level. However, the McCallum model failed to possess attributes that increased the explanatory power 
of all models, even at the 5-percent level, if we excluded the world unemployment rate as regressor in the McCallum model. The McCallum model is therefore not genuinely better than the other models on this score.

It is also worth noting that in all models (except Phelps) "world" variables are very significant: the deviations of world real income and world unemployment. This confirms the suspicion from the visual presentation in Figure 1. However, we need to explain this common world experience.

Post sample comparison. The last column of Table 5 lists the mean squared errors (MSE) of the dynamic forecasts for the period 1989-1993 which suggests the following ranking of models: L\&N, second order autoregressive model, McCallum, B\&S, and Phelps.

As the model comparison criteria give conflicting indications, it is not clear-cut which is the best model. Not surprisingly, the second order autoregressive model is the worst within sample performer. However, if one uses the post sample criteria the autoregressive model is only overtaken by the L\&N model. This result is somewhat disappointing as the post sample criteria are probably more informative about the performance of the models than the within sample criteria.

\section{Why are Some of Our Results Different from the Authors' Results?}

Though it is not surprising that our results are in some cases different from the authors' own results, it nevertheless begs the question of why they are different. We have already noted in the introduction that the authors in most cases fail to deal properly with the time-series properties of the data, which is of course an important reason for the discrepancy. Furthermore, from reading the original papers one gets the impression that a substantial pretesting and specification search has taken place prior to the presentation of their results. Another problem with some of the authors' own estimates is that they fail to distinguish between economic and statistical significance. 10 The analysis in section 5 showed that some

10 The failure to distinguish between economic and statistical significance seems to be a malaise in the economic literature (see M cCloskey and Ziliak (1996)). 
variables are statistically significant without being economically significant, as revealed in the model simulations. We now turn to a discussion of each model.

The L\&N model. The discrepancy between the result of $L \& N$ and our result is likely to be a result of different estimation technique and different model reduction procedure. In their 1986 model the NAIRU is basically driven by wage push factors in their wage equation. Since real wages and most of the wage push factors have been trending upward over most of their estimation period, and L\&N estimate in levels, it is not surprising that they find a positive relationship between real wages and wage push factors, although the relationship may be entirely spurious. Clearly, the t-ratios attached to their coefficient estimates do not follow the standard t-distribution. Furthermore, L\&N do not use a consequent model reduction strategy. Madsen (1994b) has shown that one comes up with entirely different model if the general-to-specific model strategy is applied to their model and their data. Finally, $\mathrm{L} \& \mathrm{~N}$ impose the restriction that the labour force participation rate is constant in the estimation period, a restriction which is strongly rejected for the OECD countries (Madsen (1994b)). Hence, this restriction leads to biased results.

Concerning the between estimates the discrepancy between our and L\&N's results in Layard et al. (1991) becomes greater. We were able to replicate their results. However, their results were sensitive to minor changes in estimation period, country sample, and the included regressors.

The B\&S model. B\&S get coefficient estimates which are consistent with ours (note that they do not measure unemployment in logs in some of their estimates). The disagreement seems to be the interpretation of the estimates. B\&S's only evaluate the sign and the statistical significance of the coefficients on the real wage gap. They do not discuss the quantitative effects of the real wage gap on unemployment in relation to their estimated models. They therefore do not notice that the real wage gap can explain only a fraction of the increase in the OECD unemployment.

The McCallum model. It is somewhat difficult to compare our and McCallum's results since McCallum estimates his model over a very short period in which unemployment was increasing over most of the period in all countries. Furthermore, McCallum included a squared time trend over the 
period 1981-83, which explained 1.6 percentage point increase in the unemployment rate for the average OECD country. World unemployment and the squared time trend explains most of the increase in unemployment in his estimates. Our estimates seem to be supportive of his model.

The Phelps model. The most important discrepancy between his and our estimates is the sign of the coefficient on the world real interest rate. However, the discrepancy is easy to explain. If we measure inflation expectations as the actual rate of inflation, as Phelps (1994), the coefficients become 0.054(48.6) and 0.005(2.91) on the unlagged and lagged world real interest rates, using the Kmenta estimator (note that unemployment is not measured in logs in Phelps' estimates). However, though the world real interest rate is now statistically significant it is not an important contributor to OECD unemployment. Simulations over the period 1973-1993 revealed that world real interest rates, calculated as in Phelps, contributed to a 0.17 percent point increase in unemployment in the average OECD country.

Concerning the sign on the world real interest rate, the crucial question is how expected inflation is most correctly measured. There are several papers from the 1970s which deal with that issue. However, the important point here is which method is consistent with Phelps' model. Since the models which underpin Phelps' empirical model assume perfect foresight, the model consistent inflation expectations are rational inflation expectations. Hence, our rational expectations measure of inflation expectations is more consistent with Phelps' theoretical models than his own measure. However, this measure of expected inflation gives an incorrectly signed world real interest rate.

\section{Conclusion and Agenda for Future Research}

In this paper we have compared four major macroeconomic models that have been used to explain unemployment in the OECD. Although the models performed reasonably well in terms of usual diagnostics in within sample comparisons, many key variables were incorrectly signed, and the constant terms explained a substantial part of the increase in unemployment, which indicates that important explanatory variables have been omitted from the models. Furthermore, model simulations indicated that the models could only explain a minor proportion of the increase in the OECD unemployment. 
Also of concern is that a simple second order autoregressive model outperformed three of the models in post sample forecasts, and contained a constant term which was lower than the constant term in the Phelps model and equal to the constant term in the Bruno and Sachs model.

Though this is all discouraging there are, however, important aspects of the Layard and Nickell and the Bruno and Sachs models, which are worth mentioning. The coefficient on the real wage gap was very robust to estimation technique, estimation period and model specification, suggesting that it is probably a better diagnostic tool than has been recently been suggested in the literature (see for instance Bean (1994), Layard and Nickell (1986)). In the Layard and Nickell model the relative decline in manufacturing employment was very significant in explaining unemployment over time, both in a statistical and in an economic sense. It, however, was not statistically significant in the long-run estimates. Whether this reflects the low efficiency of our long-run estimates or that the labour market has adjusted to the manufacturing employment decline in the long-run has to be uncovered by more disaggregated data. Furthermore, it has to be explained why manufacturing employment has declined as a proportion of total employment in most OECD countries since 1973. The manufacturing real wage gap has declined in all OECD countries since the mid 1970s, pointing towards an increase in manufacturing employment. However, despite this development manufacturing employment has continued its decline during the 1980s and 1990s suggesting that there is something more fundamental taking place in manufacturing, than traditional neoclassical theories are able to explain. The missing explanation may lie in technological change. An inquiry into that is urgently needed.

So what are the lessons from this study? The models assumed that the secular rise in the OECD unemployment is due to adverse supply side shocks or developments. Our estimates indicated that supply side factors are not important for unemployment, which concur with the conclusion of Bean (1994). The real wage gap was the only supply side variable, which produces robust results and despite that it explained less than 1 percentage point of the rise in the OECD unemployment since 1973. Perhaps the economics profession should turn their attention toward other culprits than real wages and why unemployment is persistent due to other factors than real wages (the traditional hysteresis theories tend to focus on real wages as the trigger, though not cause, of hysteresis in unemployment). Both the demand and supply of labour has to be considered. On the labour demand side it may be worth 
exploring whether markups have increased and labour saving technological progress have contributed to the declining employment in some countries. Concerning labour supply it is well known that the female labour force participation rate has increased substantially in the OECD countries. Some economists have looked into the rise in the rise in the female labour force participation as a contributor to unemployment (Gregory (1992), for instance). However, the theory behind this has not yet been developed and not much empirical work has been done in this area. Finally, much research has been devoted to explain differences in unemployment due to institutional and other country specific factors (Calmfors and Driffil (1988), Bruno and Sachs (1985), Blanchard and Summers (1986)). However, our estimates demonstrated that the models were unstable over time, but uniform across countries, in contrast to common perception among economists. It may, therefore, be useful to reorient the attention towards the structural changes, which have occurred over time, and away from geographical location. Clearly, there is an enormous task ahead. 


\section{APPENDIX: Variable list, data sources and tests for unit root}

Numbers in brackets are t-bar statistics, suggested by Im et al. (1995). The numbers in the parentheses attached to the t-bar statistics are probability values from the standard normal distribution. Note that only negative t-bar statistics reject the null hypothesis of unit root. Hence, probability values are not attached to positive t-bar statistics.

All variables with the subscript $\mathrm{c}$ are their $\log$ deviation from a time trend and a squared time trend.

$\mathrm{U}_{\mathrm{w}} \quad$ unemployment rate (LFS;MEI) [-1.46(0.07)]

$\mathrm{P}^{\mathrm{w}} / \mathrm{P}^{\mathrm{o}} \quad$ unweighted average of manufacturing import and export price competitiveness (HTS,WT,TS,SY, and national sources). Import price competitiveness is calculated as manufacturing import prices divided by manufacturing output prices on the domestic market (MEI,IFS). Export price competitiveness is calculated as a multilateral index which takes third market penetration on export markets into account. The weighting matrix is calculated as the following. Define $\mathbf{X}$ is an $\mathbf{n} \times \mathbf{m}$ matrix, where the element $x_{j}$ is the sales of country $i$ to country, $n$ is the number of countries, and $m$ is the number of markets. The same suppliers and markets are considered, implying that $\mathbf{n}=\mathbf{m}$. Given $\mathbf{R}=\mathbf{X} /\left(\mathbf{X}^{\prime} \mathbf{c}\right)$ and $\mathbf{V}=$ $\mathbf{X} / \mathbf{X c})$, where $\mathrm{c}$ is a $\mathrm{n} \mathrm{x} 1$ vector and / is the Hadamart division. $R$ is the the share of country i's export sold in market $\mathrm{j}$ and $\mathrm{V}$ is the share of country i's market in country $\mathrm{j}$. Then the weights are calculated from the matrix $\mathbf{Z}=(\mathbf{R V})^{*} \mathbf{A}$, where * is the Hadamart product and $\mathrm{A}$ is an $\mathrm{n} \mathrm{x}$ m matrix of all off-diagonal elements of one and zero diagonal elements. The elements are finally adjusted to sum to 1 in each row. $\mathbf{X}$ is calculated as the following with data for 21 OECD countries in 1981 (OECD minus Turkey, Luxembourg, Mexico, and former Yugoslavia): The diagonal elements are manufacturing turnover (SY) minus total manufacturing exports (TC, SITC 5,6, 8 and 9) for each country. The offdiagonal elements are from (TC, SITC 5,6, 8 and 9). All sales are converted to USD (IFS). [-0.40 (0.34)] and [1.46 for $\left.\left(\mathrm{P}^{\mathrm{w}}-\mathrm{P}^{\mathrm{o}}\right) \mathrm{v}\right]$

$\Delta \mathrm{p}^{\mathrm{c}} \quad$ consumer price inflation (IFS)

$\Delta \mathrm{p}^{\mathrm{e}} \quad$ expected consumer price inflation generated recursively over 10-years intervals with the following explanatory variables lagged one period: growth rate in M1 (IFS), the level of unemployment, growth in hourly wage rate in manufacturing, and growth rate inconsumer prices.

$\Delta \mathrm{p}^{\mathrm{u}} \quad$ unanticipated consumer price inflation: $\mathrm{p}^{\mathrm{c}}-\mathrm{p}^{\mathrm{e}}[-14.24(0.00)]$

G real government spending (IFS) [7.45]

$\mathrm{Y}^{\mathrm{w}} \quad$ world real income calculated as total real GDP (NA) in the OECD countries weighted by manufacturing exports (TC, SITC 5,6, 8 and 9) for each country in 1981 [3.47]

MM job mismatch. Three different measures used; (i) long-term unemployment (OECD database) to total unemployment [2.01], (ii) shifts out of the UV-relationship as described in the text, where vacancies are from (MEI) [12.70]; and (iii) the ratio of manufacturing employment (LFS,YB) to total employment (YB) [2.06].

$v \quad$ imports plus exports of goods and services (IFS) divided by two times nominal GDP (NA)

$\mathrm{P}^{\mathrm{m}} / \mathrm{P}^{\mathrm{o}}$ manufacturing import unit value (IFS) ratio to manufacturing output prices (wholesale prices are used if producer prices are not available) (MEI;IFS) [-0.54(0.29)]

$\mathrm{P}^{\mathrm{m}} / \mathrm{P}^{\mathrm{va}}$ manufacturing import unit value (IFS) ratio to manufacturing value-added price deflator (NA) [0.06]

$\mathrm{T}_{\mathrm{d}}^{\mathrm{i}} \quad$ average indirect tax rate calculated as total indirect taxes (NA) divided by nominal GDP (NA) [0.24]

$\mathrm{T}^{\mathrm{d}} \quad$ average direct tax rate calculated as total direct taxes (NA) divided by nominal GDP (NA) [3.90]

$\mathrm{T}^{\mathrm{p}} \quad$ employee taxes calculated as total hourly labour costs divided by weekly hours worked in non-agricultural activities (YB) and the hourly direct wage (YB,MEI,IFS) [0.58]

$\mathrm{W} / \mathrm{P}^{\mathrm{va}} \quad$ real wages with the value-added price-deflator as price variable. Wages are calculated as total hourly labour costs calculated as compensation to employees (NA) divided by total employment (LFS, YB) and weekly hours worked in non-agricultural activities (YB). The value-added price-deflator is calculated as nominal GDP (NA) divided by real GDP (NA). [4.58]

$\mathrm{W}^{\mathrm{X}} \quad$ real wage gap (see under the B\&S model section 5 for construction) [0.46]

$\mathrm{N}$ total employment (LFS,YB)

$\mathrm{S}_{\mathrm{k}} \quad$ capital share of national income calculated as net operating surplus (NA) divided by nominal GDP (NA) [0.02]

$\mathrm{K} \quad$ net capital stock in fixed prices (OECD database)

$\mathrm{M} 1 / \mathrm{P}^{\mathrm{c}} \quad \mathrm{M} 1$ (IFS) deflated by consumer prices (IFS) [1.82]

$\mathrm{POP}^{\mathrm{y}}$ proportion of population in the age of 20 to 24 years to population of working age (LFS,YB). Exponential interpolation and national sources are used in years where data are not available [1.70]

$\mathrm{OR}^{\mathrm{W}} \quad$ real oil price calculated as USD oil prices (IFS) divided by US manufacturing producer prices (IFS) [6.59] 
$\mathrm{IR}^{\mathrm{w}} \quad$ world real interest rate computed as the weighted average of the longterm interest rate on government bonds (IFS), minus consumer price inflation expectations $\left(\Delta \mathrm{p}^{\mathrm{e}}\right)$. The weights are the USD GDP shares of the 22 OECD countries considered [-12.87 (0.00) performed for all countries as a panel]

$\Psi \quad$ ratio of Okun's Law coefficient to the unweighted world average, where Okun's law coefficient is the coefficient on ycyc from the regression (in levels) $\mathrm{u}=\mathrm{a}_{0}+\mathrm{a}_{1} \mathrm{y}^{\mathrm{cyc}}+\mathrm{a}_{2}$ time $+\mathrm{a}_{3} \mathrm{t}^{2}+$ error, where $\mathrm{y}$ cyc is the deviation of the $\log$ real GDP from its trend, where trend income is estimated using the Hodrick-Prescott filter with $\mathrm{m}$ set to 1600.

$\varepsilon \quad$ the ratio of the real wage elasticity of labour demand to the unweighted world average, where the real wage elasticity of labour demand is the value of $\left(b_{4}+b_{5}\right) /\left(1-b_{1}\right)$ from the regression (in levels) $\mathrm{t}_{t}=\mathrm{b}_{0}+\mathrm{b}_{1} \mathrm{l}_{\mathrm{t}-1}+\mathrm{b}_{2} \mathrm{y}_{\mathrm{t}}+\mathrm{b}_{3} \mathrm{y}_{\mathrm{t}-1}+\mathrm{b}_{4}(\mathrm{w}$ $\mathrm{p})_{\mathrm{t}}+\mathrm{b}_{5}(\mathrm{w}-\mathrm{p})_{\mathrm{t}-1}+$ error, where 1 is measured as total employment (LFS,YB) times weekly hours worked (YB). $y_{t}$ and $(\mathrm{w}-\mathrm{p})_{\mathrm{t}}$ are instrumented. The instruments used for $(\mathrm{w}-\mathrm{p})_{\mathrm{t}}$ are the same as those used for real wages in table 3. Following instruments are used for $\mathrm{y}_{\mathrm{t}}: \mathrm{y}_{\mathrm{t}-1}, \mathrm{y}_{\mathrm{t}}^{\mathrm{W}}, \mathrm{y}^{\mathrm{W}}{ }_{\mathrm{t}-1}, \operatorname{tr}^{\mathrm{W}}{ }_{\mathrm{t}}, \operatorname{tr}^{\mathrm{W}}{ }_{\mathrm{t}}, \mathrm{r}_{\mathrm{t}}, \mathrm{r}_{\mathrm{t}-1}, \mathrm{~h} 0_{\mathrm{t}}, \mathrm{h} 0_{\mathrm{t}-1}$, where $\operatorname{tr}^{\mathrm{W}}$ is world trade (export) volume (IFS) and $\mathrm{r}$ a is long-term government bond interest rate

$\mathrm{U}^{\mathrm{w}} \quad$ world unemployment rate, calculated as the weighted unemployment rate for the 22 OECD countries considered in the paper, with labour force (YB,LFS,MEI) as weights. The own country unemployment is excluded [-1.10 $(0.20)$ for $\left.\mathrm{U}^{\mathrm{w}} \mathrm{v}\right]$

$\rho \quad$ macro replacement ratio (Chan-Lee (1987)) [0.56]

Instruments: world food prices (IFS), credit to the private sector (IFS), H0 (IFS), exchange rate vis-a-vis USD (IFS).

\section{DATA SOURCES}

IFS = International Financial Statistics, IMF

LFS = Labour Force Statistics, OECD

MEI = Main Economic Indicators, OECD

$\mathrm{NA}=$ National Accounts, OECD

YB = Yearbook, ILO

TIC $=$ Trade in Commodities, OECD

HTS $=$ Historical Trade Statistics, OECD

WT $=$ World Tables, World Bank

TS = Trade Statistics, OECD

$\mathrm{SY}=$ Statistical Yearbook, UN

$\mathrm{TC}=$ Trade in Commodities, OECD 


\section{REFERENCES}

Andrews, Martyn and Stephen Nickell, 1982, "Unemployment in the United Kingdom Since the War," Review of Economic Studies, XLIX, 731-759.

Ball, Laurence, 1996, “Disinflation and the NAIRU,” NBER Working Paper 5520, March.

Ball, Laurence, 1999, “Aggregate Demand and Long-Run Unemployment”, Brookings Papers on Economic Activity, 0(2), 189236.

Baltagi, Baldi H, 1995, Econometric Analysis of Panel Data, Wiley: West Sussex, UK.

Baltagi, Baldi H and J M Griffin, 1984, "Short and Long Run Effects in Pooled Models," International Economic Review, 25, 745753.

Bean, Charles R., 1994, "European Unemployment: A Survey," Journal of Economic Literature, 112, 573-619.

Bean, Charles R, P Richard G Layard, and Stephen J Nickell, 1986, "The Rise in Unemployment: a Multicountry Study," Economica, 53, S1-S22.

Blanchard, O. and J. Wolfers, 2000, "The Role of Shocks and Institutions in the Rise of European Unemployment: The Aggregate Evidence”, Economic Journal, 110, C1-C33.

Bruno, Michael, 1986, "Aggregate Supply and Demand Factors in OECD Unemployment: an Update." Economica, 53, S35-S52.

Bruno, Michael and Jeffrey D Sachs, 1985, Economics of Worldwide Stagflation. Harvard University Press: Cambridge, MA.

Chan-Lee, James H, David T Coe and Menahem Prywes, 1987, "Microeconomic Changes and Macroeconomic Wage Disinflation in the 1980s," OECD Economic Studies, 8, Spring, 121-157.

Dziechciarz, Jozef, 1990, "Changing and Random Coefficient Models. A Survey," in Peter Hackl (ed), Statistical Analysis and Forecasting of Economic Structural Change, Berlin: Springer-Verlag, 217-251.

Glyn, Andrew and Bob Rowthorn, 1988, "West European Unemployment: Corporatism and Structural Change," American Economic Review, Papers and Proceedings, 78, 194-199.

Gregory, Robert J, 1991, " A LEGO Approach to the Australian Labour Market," Economic Record.

Grubb, Dennis, Richard Jackman and Richard Layard, 1983, "Wage Rigidity and Unemployment in OECD Countries," European Economic Review, 21, 11-39.

Hamilton, James D, 1994, Time Series Analysis, Princeton University Press: Princeton, NJ.

Hoon, H Teck and Edmund S. Phelps, 1992, "Macroeconomic Shocks in a Dynamised Model of the Natural Rate of Unemployment", American Economic Review, 82, 889-900.

Hsiao, Cheng, 1975, "Some Estimation Methods for a Random Coefficient Model,” Econometrica, 43, 305-325.

Im, Kyung-So, M Hashem Pesaran and Yongcheol Shin, 1995, “Testing for Unit Roots in Heterogeneous Panels", Department of Applied Economics Working Paper 9526, Cambridge.

Junankar, P.N., 1981, "An Econometric Analysis of Unemployment in Great Britain, 1952-75", Oxford Economic Papers, 33 (3), November , 387-400. 
Junankar, P.N. \& S. Price, 1984, The Dynamics of Unemployment: Structural Change and Unemployment Flows, Economic

Journal, Conference Papers, 94, 158-165.

Kmenta, Jan, 1986, Elements of Econometrics, Macmillan, London.

Layard, Richard and Stephen Nickell, 1985a, "The Causes of British Unemployment," National Institute Economic Review, February, 62-85.

Layard, Richard and Stephen Nickell, 1985b, "Unemployment, Real Wages, and Aggregate Demand in Europe, Japan, and the United States," Journal of Monetary Economics, Supplement: Carnegie-Rochester Conference Series on Public Policy, no. 23, 143-202.

Layard, Richard and Stephen Nickell, 1986, "Unemployment in Britain," Economica, 53, S121-S169.

Layard, Richard, Stephen Nickell and Richard Jackman, 1991, Unemployment: Macroeconomic Performance and the Labour Market, Oxford: Oxford University Press.

Leamer, Edward E, 1978, Specification Searches: Ad Hoc Inference with Nonexperimental Data. Wiley: NY.

Leamer, Edward E, 1995, "Testing Trade Theory," in David Greenaway and Alan Winters (eds), Surveys in International Trade. Blackwell, 66-94.

Madsen, Jakob B, 1994a, “Wage Gap and Technology,” Kyklos, 47, 95-108.

Madsen, Jakob B, 1994b, "The Rise in the UK Unemployment: the Search for an Explanation," International Review of Applied Economics, 8, 251-265.

Madsen, Jakob B, 1988, General Equilibrium Macroeconomic Models of Unemployment: Can They Explain the Unemployment Path in the OECD?, Economic-Journal; 108(448), 850-67.

McCallum, John, 1986, "Unemployment in OECD Countries in the 1980s", Economic Journal, 96, 942-960.

McCloskey, Deirdre N and Stephen T Ziliak, 1996, "The Standard Error of Regressions," Journal of Economic Literature, XXXIV, 97-114.

McElroy, M B, 1977, "Weaker MSE Criteria and Tests for Linear Restrictions in Regression Models With Non-spherical Disturbances," Journal of Econometrics, 6, 389-394.

Nickell, Stephen, 1990, "Unemployment: A Survey," Economic Journal, 100, 391-439.

Nickell, Stephen, 1997, "Unemployment and Labor Market Rigidities: Europe versus North America”, Journal of Economic Perspectives, 11(3), 55-74.

Nickell, S. and R. Layard , 1999 "Labor Market Institutions and Economic Performance”, in Handbook of Labor Economics, vol. 3, edited by O. Ashenfelter and D. Card, Elsevier, Amsterdam.

Nickell, S. L. Nunziata, W. Ochel and G. Quintini, 2001, "The Beveridge Curve, Unemployment and Wages in the OECD form the 1960s to the 1990s", Centre for Economic Performance, London School of Economics.

Pagan, Adrian, 1994, "Three Econometric Methodologies: an Update," in Les Oxley, Donald R George, Colin J Roberts and Sturt Sayer (eds), Surveys in Econometrics, 30-41.

Pesaran, M Hashem and Ron Smith, 1995, "Estimating Long-run Relationships From Dynamic Heterogeneous Panels," Journal of Econometrics, 68, 79-113. 
Pesaran, M Hashem, 1997, “The Role of Economic Theory in Modelling the Long Run,” Economic Journal, 107(440), $178-91$.

Phelps, Edmund S, 1992 "Consumer Demand and Equilibrium Unemployment in a Working Model of the Customer Market Incentive Wage Economy", Quarterly Journal of Economics, 1003-1032.

Phelps, Edmund S, 1994 Structural Slumps: The Modern Equilibrium Theory of Unemployment, Interest, and Assets, Cambridge, Mass.: Harvard University Press.

Rausser, G C, Mundlak, Y, and Johnson, S R, 1982, "Structural Change , Updating, and Forecasting," in G C Rausser (ed), New Directions in Econometric Modelling and Forecasting US Agriculture. Amsterdam: North Holland.

Sachs, Jeffrey D, 1983, "Real wages and unemployment in the OECD countries," Brookings Papers on Economic Activity, No. 1, 255-304.

Swamy, P A V B, 1971, Statistical Inference in Random Coefficient Regression Models. Lecture Notes in Operations Research and Mathematical Systems 55. Springer-Verlag: Berlin.

Zellner, Arnold, 1962, “An Effficient Method of Estimating Seemingly Unrelated Regression and Tests for Aggregation Bias," Journal of the American Statistical Association, 64, 977-992. 
Table 1. Parameter estimates of the L\&N model (equation 1)

\section{KMENTA ESTIMATOR}

\begin{tabular}{|c|c|}
\hline$\Delta u_{t-1}$ & $0.099(4.92)$ \\
\hline$\Delta u_{t-2}$ & $-0.160(9.29)$ \\
\hline$\Delta g_{t}$ & $-1.590(17.8)$ \\
\hline$\Delta y^{C W_{t}}$ & $-4.383(24.6)$ \\
\hline$\Delta y^{C w} w_{t-1}$ & $-3.363(16.1)$ \\
\hline$\Delta \mathrm{MM}_{\mathrm{t}}$ & $-1.458(20.8)$ \\
\hline$\Delta \mathrm{T}_{\mathrm{t}-1}$ & $3.932(20.6)$ \\
\hline Con & $0.026(8.81)$ \\
\hline$F(220,418)^{1}$ & 1.45 \\
\hline $\mathrm{R}^{2}$ & 0.87 \\
\hline DW & 1.89 \\
\hline$\chi^{2}(7)$ & 18.33 \\
\hline $\mathrm{ARCH}$ & 1.01 \\
\hline $\operatorname{RESET}(2)$ & 0.06 \\
\hline Chow $(8,534)$ & 8.71 \\
\hline $\mathrm{PF}$ & 9.60 \\
\hline AIC & 0.68 \\
\hline SWC & 0.72 \\
\hline MSE & 0.15 \\
\hline MAE & 0.19 \\
\hline Crit (F) & 16.94 \\
\hline
\end{tabular}

\section{HSIAO ESTIMATOR}

\begin{tabular}{|c|c|}
\hline$\Delta u_{t-1}$ & $0.276(4.83)$ \\
\hline$\Delta\left(\mathrm{p}^{\mathrm{W}}-\mathrm{p}^{0}\right) \mathrm{t}$ & $0.882(-$ \\
\hline$\Delta g^{C} t$ & $-0.286(0.15)$ \\
\hline$\Delta y^{C w^{*}}$ & $-3.7131-$ \\
\hline$\Delta \mathrm{MM}_{\mathrm{t}}$ & $-2.236(-$ \\
\hline$\Delta \mathrm{T}_{\mathrm{t}}$ & $1.6341-$ \\
\hline$v \Delta\left(\mathrm{p}^{\mathrm{m}}-\mathrm{p}^{0}\right) \mathrm{t}$ & $-0.117(1.72$ \\
\hline$\Delta \mathrm{T}^{i} \mathrm{t}$ & $-1.073(0.18$ \\
\hline$\Delta \mathrm{TP}_{\mathrm{t}}$ & $0.974(0.69$ \\
\hline$\Delta^{2} p u_{t}$ & $-0.012(1.20)$ \\
\hline Con & $0.0281-$ \\
\hline
\end{tabular}

\section{SWAMY ESTIMATOR}

$\begin{array}{lr}\Delta \mathrm{u}_{\mathrm{t}-1} & 0.243(4.15) \\ \Delta\left(\mathrm{p}^{\mathrm{W}}-\mathrm{p}^{\circ}\right)_{\mathrm{t}} & 0.389(1.26) \\ v \Delta\left(\mathrm{p}^{\mathrm{m}}-\mathrm{p}^{\circ}\right)_{\mathrm{t}} & -0.326(2.20) \\ \Delta \mathrm{g}^{\mathrm{C}} \mathrm{t} & -0.269(0.28) \\ \Delta \mathrm{y}^{\mathrm{C}} \mathrm{w}_{\mathrm{t}} & -4.477(3.77) \\ \Delta \mathrm{MM}_{\mathrm{t}} & -1.525(2.85) \\ \Delta \mathrm{T}_{\mathrm{i}}^{\mathrm{i}} & 0.502(0.20) \\ \Delta \mathrm{T}_{\mathrm{t}} & 0.444(0.31) \\ \Delta \mathrm{T}_{\mathrm{t}} & 0.426(0.46) \\ \Delta^{2} \mathrm{p}_{\mathrm{t}}^{\mathrm{u}} & -0.002(0.79) \\ \mathrm{Con} & 0.020(1.42)\end{array}$

Notes: t-statistics in parentheses. A ( - ) signifies that the standard error is negative.

$\mathrm{MM}$ is measured as manufacturing employment relative to total employment. $\mathrm{F}(\mathrm{i}, \mathrm{j})=\mathrm{F}-$ test for coefficient homogeneity across countries using OLS estimates over the estimation period 1964-1993, F(i,j)-distributed under the null hypothesis of crosscountry coefficient homogeneity, $\mathrm{R}^{2}=$ Buse R-squared, DW = Durbin-Watson test of first order serial correlation, $\chi^{2}(\mathrm{i})=$ Breusch-Pagan test for heteroscedasticity, $\chi^{2}$ (i)distributed under the null of homoscedasticity, $\mathrm{ARCH}=$ Engle's test for autoregressive conditional heteroscedasticity, $\chi^{2}$ (1)-distributed under the null of no ARCH, RESET(2) $=$ RESET functional form test of the power of two and three, $\chi^{2}(2)$-distributed under the null of right functional form, Chow $(i, j)=$ F-test for coefficient constancy in the two subperiods 1964-1975 and 1976-1988, $F(i, j)$-distributed under the null hypothesis of coefficient constancy, PF = predictive failure test, over the period 1989 to $1993, \chi^{2}(5)$ distributed under the null hypothesis of no predictive failure, AIC = Akaike's Information Criterion, SWC = Schwart Criterion, MSE = mean square error in the forecast period 1989 to 1993, MAE = mean absolute error in the forecast period 1989 to 1993, VS Mc, Ph and B\&S = J-test of whether attributes of the models of the models of Mc (McCallum), Ph (Phelps) and B\&S can add to the explanation of the variance in unemployment, $\chi^{2}(1)$-distributed under the null hypothesis of no contribution. Note that the predicted value of all the models ( $\mathrm{MC}, \mathrm{Ph}$ and $\mathrm{B} \& S$ ) are simultaneously included in the J-test regression, and $\mathrm{Crit}(\mathrm{F})=$ Critical value of the F-test for pooling calculated from the Leamer formula of flat prior. Estimation period 1964 to 1993 minus 5 years used for forecasts.

1. P-value $=0.001$. 
Table 2. Parameter estimates of the B\&S model (equation 2)

\section{KMENTA ESTIMATOR}

\begin{tabular}{|c|c|c|c|}
\hline$\Delta u_{t-1}$ & $0.161(7.73)$ & $\Delta u_{t-1}$ & $0.188(1.69)$ \\
\hline$\Delta u_{t-2}$ & $-0.153(9.05)$ & $\Delta u_{t-2}$ & $-0.114(2.85)$ \\
\hline$\Delta \mathrm{w}_{\mathrm{t}}{ }_{\mathrm{t}}$ & $0.235(11.0)$ & $\Delta w^{x_{t}}$ & $0.184(0.31)$ \\
\hline$\Delta w^{x_{t-1}}$ & $0.336(15.1)$ & $\Delta w^{x_{t}}$ & $0.6821-$ \\
\hline$\Delta(\mathrm{m} 1-\mathrm{p} c \mathrm{pi}) \mathrm{C}_{\mathrm{t}}$ & $0.264(7.95)$ & $\Delta\left(\mathrm{m} 1-\mathrm{p}^{\perp} \mathrm{cpi}\right) \mathrm{C}_{\mathrm{t}}$ & $0.031(-$ \\
\hline$\Delta\left(\mathrm{m}_{1}-\mathrm{p} \mathrm{cpi}^{-}\right)_{t-1}$ & $-0.944(29.6)$ & $\Delta\left(\mathrm{m} 1-\mathrm{p}^{\mathrm{cp}}\right)^{\mathrm{C}} \mathrm{C}_{\mathrm{t}-1}$ & $-0.791(3.60)$ \\
\hline$\Delta y^{C w_{t}}$ & $-3.736(20.3)$ & $\Delta \mathrm{y}^{\mathrm{CW}} \mathrm{t}$ & $-3.901(-$ \\
\hline$\Delta \mathrm{y}^{\mathrm{CW}} \mathrm{t}_{\mathrm{t}-1}$ & $-3.042(13.5)$ & $\Delta \mathrm{y}_{\mathrm{C}} \mathrm{W}_{\mathrm{t}}$ & $-2.097(-$ \\
\hline Con & $0.046(15.7)$ & Con & $0.0551-$ \\
\hline
\end{tabular}

$F(176,352)^{1} \quad 2.30$

$\mathrm{R}^{2} \quad 0.86$

DW 1.91

$\mathrm{BP} \chi^{2}(8) \quad 9.01$

$\mathrm{ARCH} \quad 0.66$

$\operatorname{RESET}(2) \quad 0.73$

Chow $(9,510) \quad 1.29$

$\mathrm{PF}$

9.45

AIC

0.643

SWC

0.691

MSE

MAE

0.20

0.20

Crit (F)

\section{SWAMY ESTIMATOR}

\begin{tabular}{lr}
$\Delta \mathrm{u}_{\mathrm{t}-1}$ & $0.197(2.47)$ \\
$\Delta \mathrm{u}_{\mathrm{t}-2}$ & $-0.100(1.60)$ \\
$\Delta \mathrm{w}_{\mathrm{t}}$ & $0.147(0.66)$ \\
$\Delta \mathrm{w}_{\mathrm{t}-1}$ & $0.495(2.59)$ \\
$\Delta(\mathrm{m} 1-\mathrm{p} \mathrm{cpi}) \mathrm{c}_{\mathrm{t}}$ & $0.077(0.44)$ \\
$\Delta(\mathrm{m} 1-\mathrm{pcpi}) \mathrm{c}_{\mathrm{t}-1}$ & $-0.694(2.77)$ \\
$\Delta \mathrm{y}_{\mathrm{C}} \mathrm{w}_{\mathrm{t}}$ & $-3.626(3.24)$ \\
$\Delta \mathrm{y}_{\mathrm{t}-1}$ & $-1.705(1.81)$ \\
Con & $0.047(3.49)$ \\
\multicolumn{2}{c}{ BETWEEN ESTIMATOR }
\end{tabular}

$\Delta \mathrm{w}^{\mathrm{x}} 1973-93$

$0.566(2.40)$

Con

$0.041(6.06)$

Notes: see notes to table 1.

1. $\mathrm{P}$-value $=0.000$. 
Table 3. Parameter estimates of the McCallum model (equation 5)

\section{KMENTA ESTIMATES}

HSIAO ESTIMATES
$\Delta u_{t-1}$
$0.161(8.76)$
$\Delta u_{t-2}$
$-0.260(14.5)$
$\Psi \Delta \mathrm{g}^{\mathrm{C}_{\mathrm{t}}}$
$-1.475(12.7)$
$\Delta u_{t-1}$
$0.284(3.11)$
$\Psi \Delta(\mathrm{m} 1-\mathrm{p} c \mathrm{pi}) \mathrm{C}_{t}$
$0.517(10.4)$
$\Psi \Delta\left(\mathrm{p}^{\mathrm{m}}-\mathrm{p}^{\mathrm{Va}}\right) \mathrm{t}$
$-2.060(-)$
$\Psi \Delta g^{C} t$
$-0.326(1.78)$
$\Psi \Delta \mathrm{uW}_{\mathrm{W}}$
$0.139(0.36)$
$\Psi \Delta(\mathrm{m} 1-\mathrm{p} c \mathrm{pi}) \mathrm{c}_{t-1}$
$-0.933(27.8)$
$\Psi \Delta\left(\mathrm{m} 1-\mathrm{p} c \mathrm{pi}^{\prime}\right) c_{t}-5.787(13.8)$
$\Psi \Delta \mathrm{u}_{\mathrm{t}}$
$0.465(21.0)$
$\Psi v \Delta\left(\mathrm{m} 1-\mathrm{p}^{\mathrm{Cp}}\right)^{\mathrm{C}} \mathrm{C}_{t}$
$-0.435(10.1)$
$\Psi v \Delta\left(p^{w}-p^{\circ}\right) t$
$-0.246(7.14)$
$\Psi v \Delta\left(\mathrm{p}^{\mathrm{W}}-\mathrm{p}^{0}\right) \mathrm{t}-1$
$0.526(14.4)$
$\Psi v \Delta u^{W} t-1$
$0.156(4.65)$
$\Psi \Delta\left(\mathrm{p}^{\mathrm{W}}-\mathrm{p}^{0}\right) \mathrm{t}$
$-0.152(0.03)$
$\varepsilon \Delta\left(\mathrm{w}-\mathrm{p}^{\mathrm{va}}\right) \mathrm{t}$
$-0.010(0.01)$
Con
$0.023(-)$
Con
$0.023(11.3)$

\section{SWAMY ESTIMATES}

$\begin{array}{lr}\mathrm{F}(242,396)^{1} & 1.18 \\ \mathrm{R}^{2} & 0.86 \\ \mathrm{DW} & 1.97 \\ \chi^{2}(11) & 44.76 \\ \operatorname{ARCH} & 1.90 \\ \operatorname{RESET}(2) & 0.41 \\ \operatorname{Chow}(11,278) & 12.11 \\ \operatorname{PF} & 6.27 \\ \operatorname{AIC} & 0.58 \\ \operatorname{SWC} & 0.53 \\ \operatorname{MSE} & 0.21 \\ \operatorname{MAE} & 0.21 \\ \operatorname{Crit}(\mathrm{F}) & 14.02\end{array}$

Notes: see notes to table. Real wages are instrumented using the following instruments

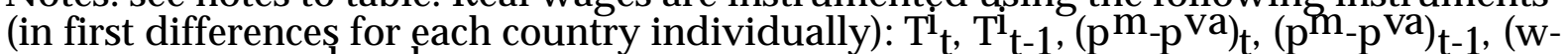
p) $t-1, h 0_{t}, h 0_{t-1}, T_{t}, \mathrm{Td}_{t-1}, q_{t}$, and $\mathrm{qt}_{\mathrm{t}-1}$, where h0 is high powered money and $\mathrm{p} v \mathrm{a}$ is the value-added price-deflator.

1. P-value $=0.075$. 
Table 4. Parameter estimates of the Phelps model (equation 6)

\section{KMENTA ESTIMATOR}

$\Delta u_{t-1}$

$\Delta u_{t-2}$

$0.152(6.12)$

$\Delta\left(\mathrm{p}^{\mathrm{W}}-\mathrm{p}^{\mathrm{O}}\right) \mathrm{t}$

$\Delta \mathrm{popY} t$

$\Delta \mathrm{popY} t-1$

$\Delta \mathrm{k}_{\mathrm{t}}$

$\Delta \mathrm{k}_{\mathrm{t}-1}$

$\Delta \mathrm{d}_{\mathrm{t}-1}$

Con

$\mathrm{F}(176,462)^{1}$
$\mathrm{R}^{2}$

DW

$\chi^{2}(8)$

$\mathrm{ARCH}$

$\operatorname{RESET}(2)$

Chow $(9,642)$

$\mathrm{PF}$

AIC

SWC

MSE

MAE

Crit (F)
$-0.203(8.95)$

$0.629(16.6)$

$-0.342(4.74)$

$0.673(9.34)$

$-7.339(20.5)$

$5.894(16.2)$

$4.928(20.8)$

$0.092(11.2)$

1.83

0.94

1.94

12.31

1.41

0.39

9.90

14.44

0.637

0.684

0.32

0.26

18.63

\section{SWAMY ESTIMATOR}

$\Delta u_{t-1}$

$0.122(1.81)$

$\Delta\left(\mathrm{p}^{\mathrm{W}}-\mathrm{p}^{0}\right)_{\mathrm{t}} \quad 0.678(1.79)$

$\Delta \mathrm{popy}_{\mathrm{t}} \quad-0.195(0.17)$

$\Delta \mathrm{D} g_{\mathrm{t}}$

$\Delta \mathrm{k}_{\mathrm{t}}$

1.E-6 $(0.05)$

$-1.884(0.87)$

$\Delta \mathrm{IR}_{\mathrm{t}} \quad-0.019(3.61)$

$\Delta \mathrm{t}_{\mathrm{t}}$

$\Delta g_{t}$

$\Delta \mathrm{or}^{\mathrm{W}} \mathrm{t}$

$\Delta^{2} \mathrm{pu}_{\mathrm{t}}^{\mathrm{u}}$

Con

$-0.091(0.03)$

$-0.242(0.30)$

$0.042(0.83)$

$-0.005(0.51)$

$0.183(2.04)$

Notes: see notes to table 1.

1. $\mathrm{P}$-value $=0.000$.

Table 5: Model Comparison

\begin{tabular}{|ll|l|l|l|l|}
\hline Model & Wrong signs $^{\mathbf{1}}$ & $\mathbf{R}^{\mathbf{2}}$ & AIC & J-test $^{2}$ & MSE \\
\hline L\&N & $44 \%$ & 0.87 & 0.68 & Mc:16.1 Ph: 0.0 B\&S: 7.7 & 0.15 \\
\hline B\&S & $0 \%$ & 0.86 & 0.64 & Mc: 5.4 Ph: 0.3 L\&N: 0.6 & 0.20 \\
\hline McCallum & $0 \%$ & 0.86 & 0.58 & Ph: 6.2 B\&S: 0.2 L\&N: 0.0 & 0.21 \\
\hline Phelps & $40 \%$ & 0.94 & 0.64 & Mc:13.6 B\&S: 0.1 L\&N: 0.6 & 0.32 \\
\hline Autoregressive & - & 0.09 & 0.89 & & 0.19 \\
\hline
\end{tabular}

